\title{
EL DERECHO DE LIBERTAD RELIGIOSA EN EL ORDENAMIENTO JURÍDICO ESPAÑ̃L (CONTENIDO DEL DERECHO FUNDAMENTAL)
}

MARÍA JOSÉ CIÁURRIZ

Profesora Titular de Derecho Eclesiástico

UNED 


\section{SUMARIO}

I. INTROdUCCIÓN.-II. PreCEDENTES hISTÓRICOS.-III. LA CONSTITUCIÓN DE 1978.-a) El "valor superior" de la libertad.-b) Libertad e igualdad.-c) Libertad, igualdad y justicia.—d) La función de justicia de la Constitución.-e) Libertad y pluralismo.-IV. Los Acuerdos con la Santa Sede de 1979.-V. El nuevo orden constituCIONAL.-a) La situación creada por la Constitución y por los Acuerdos con la Santa Sede.-b) La nueva Ley de Libertad Religiosa de 1980.-c) (Un régimen común para todas las Confesiones?-VI. LA LIBERTAD RELIGIOSA EN LA CONSTITUCIÓN Y EN LA LEY DE 5 JULIO DE 1980.--a) Libertad religiosa y libertad de culto.-b) El contenido de la libertad religiosa. - c) La libertad religiosa personal.-VII. LA LIBERTAD RELIGIOSA EN LOS ACUERDOS CON LAS CONFESIONES.-a) Los sujetos titulares de la libertad religiosa.-b) Libertad de culto y asistencia religiosa.-c) El contenido de los Acuerdos.--d) Los ministros del culto.-e) Los lugares sagrados.-f) Las funciones sagradas.-g) Las festividades religiosas y los problemas que generan.- $h$ ) La enseñanza.-i) El matrimonio.-j) La financiación de las confesiones religiosas. - $k$ ) La protección del patrimonio.-1) La asistencia religiosa en centros estatales. 


\title{
EL DERECHO DE LIBERTAD RELIGIOSA EN EL ORDENAMIENTO JURÍDICO ESPAÑOL (CONTENIDO DEL DERECHO FUNDAMENTAL)
}

\author{
POR \\ MARÍA JOSÉ CIÁURRIZ \\ Profesora Titular de Derecho Eclesiástico \\ UNED
}

\section{INTRODUCCIÓN}

En el ordenamiento jurídico español que nace de la Constitución de 1978, el derecho de libertad religiosa aparece como un derecho fundamental plenamente integrado en el supremo cuerpo legislativo $y$ en la legislación que lo desarrolla ${ }^{1}$. Dentro, en efecto, del Título I del texto constitucional, que trata "De los derechos y deberes fundamentales", el Capítulo segundo, sobre los "Derechos y libertades", en su Sección 1.a , "De los derechos fundamentales y de las libertades públicas", establece, en el artículo 16.1, que "Se garantiza la libertad ideológica, religiosa y de culto de los individuos y las comunidades...". A este precepto superior han de sumarse, para completar el panorama de la recepción dada en nuestro ordenamiento a la libertad religiosa, la Ley Orgánica de 5 de julio de 1980 y los Acuerdos firmados por el Estado español con las confesiones religiosas de mayor presencia y arraigo en España: la Iglesia católica, la Federación Española de Entidades Religiosas Evangéli-

1 Así lo expresa P. J. VILADRICH, "Los principios informadores del Derecho Eclesiástico español", en la obra de J. M. González del Valle, P. Lombardía, M. López Alarcón, R. Navarro-Valls y P. J. Viladrich, Derecho Eclesiástico del Estado Español, 2. ed., Pamplona 1983, págs. 193-195. 
cas, la Federación de Comunidades Israelitas y la Comisión Islámica de España ${ }^{2}$.

Sustituye este régimen jurídico sobre la libertad religiosa al inmediato anterior, establecido durante el Franquismo, y que se concretó en la Ley de Libertad Religiosa de 28-VI-1967 ${ }^{3}$. Ninguna otra norma específica sobre el tema había tenido nunca lugar en España, quedando la libertad religiosa como una realidad jurídica y social de mayor o menor extensión presente de algún modo en nuestras precedentes constituciones, bajo supuestos ideológicos muy distintos de los que han inspirado las dos grandes innovaciones que en este campo supusieron las mencionadas normas legales de 1967, 1978 y 1980.

\section{PRECEDENTES HISTÓRICOS}

De hecho, el acontecimiento que puso en marcha en España el reconocimiento estatal del derecho fundamental de libertad religiosa fue el Concilio Vaticano II ${ }^{4}$.

En efecto, bajo el régimen del General Franco, las llamadas Leyes Fundamentales ${ }^{5}$, base constitucional de aquel sistema político, preveian una confesionalidad del Estado que — cuando menos en el plano de las

2 Hemos publicado el texto de la Ley Orgánica de Libertad Religiosa, de 5 de julio de 1980, con toda la documentación relativa a su preparación, elaboración y desarrollo, en M. J. CláURRIz, La libertad religiosa en el Derecho Español, Madrid, 1984, págs. 190-268. La Secretaría general del Congreso de los Diputados ha publicado un volumen (Documentación; n. 98 , julio 1992) con la documentación preparada para la tramitación de los proyectos de ley de los Acuerdos con las Comunidades Religiosas Evangélicas, Islámicas e Israelitas. Incluye los textos de los tres Acuerdos J. A. Souto, Derecho Eclesiástico del Estado, Madrid, 1992, págs. 555-570, y por esta obra los citaremos siempre.

3 Vid. el texto de la Ley en J. Maldonado, Curso de Derecho canónico para juristas civiles, Madrid, 1967, págs. 479-487. La bibliografía sobre la misma es muy abundante; vid., entre otros, A. BERnÁrdez CANTón, en el vol. de VV.AA., Derecho Canónico, Pamplona, 1974, cap. XXI, "Elementos de Derecho Eclesiástico Español», págs. 790 y ss.; J. Pérez LlantadA, La libertad religiosa en España y en el Vaticano II, Madrid, 1974, passim; G. SuÁrez Pertierra, Libertad religiosa y confesionalidad en el ordenamiento jurídico español, Vitoria, 1978, passim.

4 Vid. al respecto A. DE LA HERA, "El derecho de libertad religiosa", en Nuestro Tiempo, 140, febrero 1966, págs. 172-191.

5 Ha publicado los textos de las Leyes Fundamentales que afectan al Derecho eclesiástico J. MaLdonado, op. cit., pág. 479. 
formulaciones doctrinales, al margen de sus concreciones prácticas ${ }^{6}$ suponía una adecuación plena del ordenamiento civil a las exigencias del Derecho divino, entendidas tal y como las formulaba e interpretaba la Iglesia católica ${ }^{7}$.

Hasta el Vaticano II, frente al problema de la libertad religiosa, la doctrina defendida por los autores que representaban el sentir mayoritario de la opinión católica era la de la tolerancia ${ }^{8}$, con raíces en el magisterio pontificio a partir de León XIII ${ }^{9}$ y en el Derecho Público eclesiástico ${ }^{10}$; la actitud del ordenamiento jurídico franquista frente a las opciones religiosas distintas del catolicismo fue en consecuencia una ac-

- Sobre la adecuación entre la legislación y las actuaciones prácticas del poder político bajo el Franquismo, vid. A. DE LA HERA, "Actitud del Franquismo ante la lglesia", en el vol. de VV.AA. (I. C. Ibán, coordinador), Iglesia católica y regímenes autoritarios y democráticos, Madrid, 1987, págs. 43-70, y del mismo autor "Las relaciones entre la Iglesia y el Estado en España (1953-1974)", en Revista de Estudios Políticos, 211, enero-febrero 1977, págs. 5-37.

7 Según el Principio II de la Ley de Principios del Movimiento Nacional, de 17 de mayo de 1958, "la Nación española considera como timbre de honor el acatamiento a la Ley de Dios, según la doctrina de la Santa Iglesia Católica, Apostólica y Romana, única verdadera y fe inseparable de la conciencia nacional, que inspirará su legislación". Vid. al respecto P. LombardiA, "La confesionalidad del Estado, hoy", en lus Canonicum, I, 1961, págs. 348-349; A. BERNÁRDEZ, op. cit., págs. 773 y ss.

\& Vid. las indicaciones que hacemos al respecto en M. J. CláurRIz, op. cit., pág. 24. Expone la doctrina de la tolerancia, en relación con el magisterio pontificio y el pensamiento católico del siglo XIX, I. Martin MARTinez, "Doctrina católica actual sobre las relaciones entre la Iglesia y el Estado", en VV.AA., Derecho Canónico, cit., págs. 665-666.

9 "La Iglesia se hace cargo maternalmente del grave peso de las debilidades humanas. No ignora la Iglesia la trayectoria que describe la historia espiritual y política de nuestros tiempos. Por esta causa, aun concediendo derechos sola y exclusivamente a la verdad y a la virtud, no se opone la Iglesia, sin embargo, a la tolerancia por parte de los poderes públicos de algunas situaciones contrarias a la verdad y a la justicia para evitar un mal mayor o conservar un mayor bien" (León XIII, encíclica Libertas del 20 de junio de 1888, cit. por I. Martín Martinez, op. cit., pág. $665)$.

10 «El problema de las relaciones entre el Derecho canónico y el Derecho secular es uno de los aspectos, el aspecto jurídico, del de las relaciones entre la Iglesia y el Estado, que han venido preocupando a la ciencia eclesiástica y política a través de los siglos y sobre el cual incluso se llegó a construir, desde el lado espiritual, una ciencia independiente, el llamado lus publicum ecclesiasticum, a base de la teoria que, recogiendo, como es natural, principios muy antiguos, recibió expresión en los textos pontificios sobre todo de LÉ́N XIII (especialmente en la encíclica Inmortale Dei, de 1 de noviembre de 1885), y fue muy elaborada por los escritores de dicha ciencia" (J. MALDONADO, op. cit., pág. 152; vid. de esta misma obra las págs. 155 y ss., que se refieren a la doctrina de León XIII y del iuspublicismo eclesiástico al respectol. 
titud -más o menos generosa- de tolerancia", que se concretó en una serie de normas que afectaban a las manifestaciones de fe acatólicas, el culto, la propaganda y el proselitismo, el matrimonio, el «status» de los ministros sagrados, etc. ${ }^{12}$. Junto a esa legislación que de un modo u otro afectaba a los no católicos en España, el Concordato de 1953, partiendo de la preexistente confesionalidad católica estatal, extendía a la Iglesia católica y a sus miembros un particular reconocimiento jurídico ${ }^{13}$, que la y los convertía en los únicos titulares en España de un auténtico derecho de libertad en el terreno religioso ${ }^{14}$. Una libertad, debe decirse, no solamente reconocida, sino tutelada de forma muy específica por el poder público ${ }^{15}$; tanto que, a veces, sonaba a protección regalista la que el Estado ejercía sobre la Iglesia, con todo lo que ello supone de efectivo endeudamiento de ésta a aquél ${ }^{16}$.

Las enseñanzas del Concilio Vaticano II supusieron un notable avance en esta línea doctrinal, acordes con las modificadas circunstancias ideológicas y sociales en que el mundo del siglo XX se mueve, y pa$\mathrm{ra}$ atender a las cuales fue precisamente convocado el Concilio ${ }^{17}$. En su

$"$ Vid. A. DE LA HeRA, "La situación jurídica de los no católicos en España (1812-1970)", en lus Populi Dei. Miscellanea in honorem Raymundi Bidagor, I, Roma, 1972, págs. 281-318. Vid. también P. Lombardía, "Actitud de la Iglesia ante el Franquismo", en W AA., Iglesia católica y regímenes autoritarios y democráticos, cit., págs. 81-102, y J. MaLdONADO, "Los cultos no católicos en el Derecho español", en W AA., El Concordato español de 1953, Madrid, 1956, págs. 403-429.

${ }_{12}$ Las expone en detalle A. BernÁRDEz CANTÓN, «Elementos de Derecho eclesiástico español", cit., págs. 780 y ss.

${ }_{13}$ La bibliografía sobre el Concordato español de 1953 es casi inabarcable. Vid. la que cita -así como sus observaciones al respecto- P. LoMBARDía, "Precedentes del Derecho Eclesiástico español», en J. M. González del Valle y otros, Derecho eclesiástico del Estado español, cit., págs. 126 y ss. Una revisión crítica del Concordato en A. DE LA HERA, "Kirche und Staat in Spanien", en Oesterreischisches Archiv für Kirchenrecht, 1976, Heft 2/3, págs. 107-132.

págs. 126-130.

14 Vid. P. Lombardía, "Precedentes del Derecho Eclesiástico español», cit.,

${ }_{15}$ Vid. P. Lombardia, op. cit., págs. 119-124.

16 Vid. las observaciones al respecto de A. DE LA Hera en «Kirche und Staat in Spanien», cit., passim. Claramente queda retratada la utilización de la Iglesia por el Franquismo y el sentido de las relaciones entre ambos en estas palabras de $S$. Mastellone y A. Álvarez de Morales, en Pensamiento político europeo (1815-1975), Madrid, 1991, pág. 401: "La revolución nacionalsindicalista del franquismo no será más que una política paternalista de justicia social basada en el Evangelio y la doctrina de la Iglesia»; "Lo esencial de toda la constitución ideológica en que se basa el régimen de Franco es que es un Estado católico con una visión providencialista del régimen y su Caudillon.

17 Sobre la influencia del Concilio en este tema, vid. las observaciones de P. Lombardia, "El Derecho Eclesiástico", en J. M. González del Valle y otros, Derecho Eclesiástico del Estado español, cit., págs. 80-89. 
Declaración «Dignitatis Humanae», aquél planteó la doctrina sobre la libertad religiosa desde puntos de vista nuevos y singulares ${ }^{18}$. La libertad religiosa se nos aparece en la Declaración como una libertad de coacción frente al poder civil en cuya virtud éste ha de respetar a todos los hombres en su derecho a elegir libremente la opción religiosa que prefieran y a comportarse pública y privadamente de acuerdo con la opción preferida ${ }^{19}$. La Iglesia se proclama asi defensora de un derecho fundamental de la persona humana, propio no de los católicos sino de todos los hombres; declara el carácter esencial, metajurídico, de tal derecho, concedido por Dios al hombre al dotarle de la naturaleza humana; y traslada al Estado la carga de reconocerlo, establecer sus márgenes de acción y protegerlo frente a cualquier tipo de coacción o limitación indebida ${ }^{20}$.

Al haberse proclamado confesionalmente católico comprometiéndose a adecuar su legislación al Derecho divino tal y como lo interpretase la Iglesia, el Estado franquista hubo de atemperar su legislación $^{21}$ a la enseñanza propuesta por el magisterio conciliar ${ }^{22}$. Fruto de esta necesidad y de esta decisión fue la Ley de Libertad religiosa de $1967^{23}$. No fue una ley que se refiriese a todas las confesiones religiosas

18 También es muy amplia la bibliografía al respecto. Vid. entre otros T. I. JiMÉNEZ URRESTI, Libertad Religiosa, Madrid, 1865, passim, y las citas que allí se recogen, asi como I. Martin Martinez, op. cit., págs. 695-704.

19 Vid. A. DE LA HERA, «El derecho de libertad religiosa», cit., págs. 176-180 [según el Concilio, el derecho civil de libertad religiosa «a que el hombre tiene derecho consiste en : 1) Inmunidad de coacción. 2) Que no se obligue al hombre a actuar contra su conciencia. 3) Ni se le impida obrar conforme a ella ni en público ni en privado" -pág. 176-; se trata de ideas expuestas por A. DE FUENMAYOR en una conferencia que el autor glosa en la op. cit.]. El texto conciliar correspondiente de la Declaración Dignitatis Humanae reza así en su n.. 2: "Este Concilio Vaticano declara que la persona humana tiene derecho a la libertad religiosa. Esta libertad consiste en que todos los hombres han de estar inmunes de coacción, tanto por parte de personas particulares como de grupos sociales y de cualquier potestad humana, y esto de tal manera que en materia religiosa ni se obligue a nadie a obrar contra su conciencia ni se le impida que actúe conforme a ella en privado y en público, sólo o asociado con otros, dentro de los límites debidos".

${ }^{20}$ Vid. sobre ello P. J. ViLADRICH, "Los principios informadores del Derecho eclesiástico español», cit., pár. 3, "El principio de libertad religiosa", págs. 193 y ss.

${ }^{21}$ Toda la documentación sobre la tramitación parlamentaria de la Ley de Libertad Religiosa de 1969 ha sido publicada por A. DE LA HeRA, Pluralismo y Libertad religiosa, Sevilla, 1971, págs. 97-246.

${ }^{22}$ Vid. P. Lombardía, "Precedentes del Derecho Eclesiástico español», cit., págs. 121-122.

${ }^{23}$ "La doctrina conciliar hizo necesario que el Estado español revisara su legislación $y$, en concreto, el párrafo segundo del art. 6 del Fuero de los Españoles. Sólo aboliendo el régimen de tolerancia que éste proclamaba, por el de libertad en materia religiosa, estaría acorde la legislación española —que en virtud del núme- 
y a todo tipo de creyentes; precisamente los católicos quedaban fuera de su ámbito de aplicación, ya que el ejercicio de la libertad religiosa, por lo que a ellos hacía, se regía por las Leyes Fundamentales y por el Concordato de 1953; eran las restantes confesiones y sus fieles quienes, privados hasta entonces del reconocimiento de justos y oportunos márgenes de libertad religiosa, verían su situación modificada por obra de la nueva norma ${ }^{24}$.

Se creó así un sistema de doble reconocimiento y protección de la libertad religiosa, uno más favorable para la Iglesia católica y sus fieles y otro más estricto para todas las restantes confesiones ${ }^{25}$. Sistema que no es hora de discutir en esta ocasión, y al que nos referimos como punto de partida, en este terreno, del cambio que supuso en España la sustitución de un régimen político por otro, y la entrada en vigor de la Constitución con la que alcanzaba su madurez el fenómeno histórico de transición a la monarquía parlamentaria y al sistema democrático de gobierno.

\section{LA CONSTITUCIÓN DE 1978}

La Constitución, al consagrar en su artículo 16.1 la garantía de la libertad religiosa, da entrada en su texto a un concepto que ella misma no

ro II de la Ley de Principios del Movimiento se inspiraba en la Religión Catolica-, con lo que ésta había establecido en materia de libertad religiosa. En la nueva redacción se sustituyó la actitud tolerante que hasta aquel momento había mantenido el Estado, por un régimen de libertad religiosa que coexistía con la confesionalidad católica. El párrafo segundo, en su segunda formulación, decía así: "El Estado asumirá la protección de la libertad religiosa, que será garantizada por una eficaz tutela jurídica, que, a su vez, salvaguarde la moral y el orden público". El desarrollo de este precepto se promulgó el 28 de junio de 1967 en la Ley reguladora del ejercicio del derecho de libertad religiosa" (M. J. CiÁurriz, op. cit., pág. 25). Vid. también A. MotILLA, "El proceso de formación del actual sistema de Derecho eclesiásticon, en I. C. Ibán, L. Prieto Sanchis y A. Motilla, Curso de Derecho eclesiástico, Madrid, 1991, págs. 24-29.

28-29.

${ }^{24}$ Vid. A. Bernárdez Cantón, op. cit., págs. 777-778; A. Motilla, op. cit., págs.

${ }^{25}$ "Con la promulgación de la Ley sobre libertad religiosa -el autor escribe en 1975-, en España existen dos sistemas jurídicos para el tratamiento de las cuestiones religiosas. El régimen concordatario y de reconocimiento especial para la religión católica y el régimen legal, que regula la actividad y constitución de las demás confesiones" (A. Bernárdez CANTón, op. cit., pág. 778). 
elabora ${ }^{26}$, pero que no puede dejar de poseer un sentido en la mente del legislador: el concepto de libertad religiosa, que el Franquismo pretendió tomar de una Declaración conciliar, fuente que no tiene por qué ser dejada de lado a la hora de analizar, estudiar o interpretar la Constitución; pero no ya considerándola como la única fuente posible - la interpretación autorizada del derecho divino que lleva a cabo la Iglesia- ${ }^{27}$, sino como una entre las varias que en la historia de las ideologías y del Derecho han podido ofrecer bases para la recta comprensión dé aquel derecho fundamental. Debe notarse, por otra parte, que la Constitución se inicia -artículo 1.1- con una mención de la libertad que lógicamente supone un presupuesto para cualquier otra referencia a la misma en el resto del supremo texto normativo ${ }^{28}$. Reza así, en efecto, el mencionado artículo: “España se constituye en un Estado social y democrático de Derecho, que propugna como valores superiores de su ordenamiento jurídico la libertad, la justicia, la igualdad y el pluralismo político".

\section{a) El «valor superior» de la libertad}

No corresponde a la norma constitucional hacer definiciones, y por otro lado - como hemos dejado apuntado hace un momento al referirnos a la Declaración "Dignitatis Humanae»-son múltiples las fuentes del más alto nivel que consagran la libertad como un derecho fundamental del ser humano. Notemos incluso que la propia Constitución, dentro del Título l, "De los derechos y libertades fundamentales", establece en el artículo 10.2 que "Las normas relativas a los derechos fundamentales y a

${ }^{28}$ La libertad religiosa es «el principio básico de que debe partir toda la normativa estatal en materia religiosa” (F. de P. Vera Urbano, Derecho Eclesiástico, I, Madrid, 1990, pág. 286). Vid. L. Prieto SanchIS, "Principios constitucionales del Derecho Eclesiástico españolm, en I. C. IBán, L. Prieto Sanchis, A. Motilla, op. cit., págs. 184-185.

${ }^{27}$ Lo cual sólo tiene sentido en el régimen establecido por los Principios Fundamentales del Movimiento que estuvieron vigentes bajo el período franquista, según ya ha quedado expuesto. Vid. A. Motilla, op. cit., pág. 36, con referencia a la asunción por el Estado de la doctrina de la Iglesia como sociedad jurídica perfecta $y$ a las consecuencias que de ello se derivaban.

${ }_{28}^{28} V i d$. al respecto J. M. GonzÁlez dEL. VALLE, Derecho eclesiástico español, 2. a ed., Madrid, 1991, págs. 137-138; J. J. Amorós, La libertad religiosa en la Constitución española de 1978, Madrid, 1984, págs. 169-170; P. Lombardí, "Derecho eclesiástico y libertad religiosa", en Revista de Derecho Público, 90, 1983, pág. 20; E. MOLANo, "El Derecho eclesiástico y la Constitución española", en Las relaciones entre la Iglesia y el Estado. Estudios en memoria del Profesor Pedro Lombardía, Madrid, 1989, págs. 289 y ss. 
las libertades que la Constitución reconoce, se interpretarán de conformidad con la Declaración Universal de Derechos Humanos y los tratados $y$ acuerdos internacionales sobre las mismas materias ratificados por España". Decisión que remite, como fuente de interpretación de la propia Constitución, a un concreto texto universal; remisión que no supone la exclusión, como criterios de estudio y valoración, de los que han inspirado otros muchos solemnes e importantes documentos en que los tiempos han ido recogiendo el patrimonio común de la Humanidad en el campo de los derechos y las libertades fundamentales del hombre ${ }^{29}$.

En esta línea de universal concreción de la idea contenida en el término libertad, no puede escaparse al exegeta de la norma constitucional la convicción, general en la doctrina, de que la libertad es una de las realidades más difíciles de definir de todo el mundo de lo jurídico ${ }^{30}$; una, se ha dicho, "de esas grandes palabras que desafían una definición" ${ }^{31}$. Y cuando SÁNCHEZ-AGESTA intenta abarcarla en un concepto, recurre a algo tan genérico como es definir "la libertad como el ideal de la civilización de Occidente" ${ }^{32}$, o afirmar que "como se ha advertido muchas veces, la palabra libertad se acomoda a las más varias definiciones políticas, porque quizá no haya en la retórica política palabra más fluidan ${ }^{33}$.

$Y$ cuando el mismo autor quiere descender a formulaciones más concretas del sentido de la libertad, escribirá que, "definiéndola en términos muy amplios como exención de una necesidad para el cumplimiento de un fin, la libertad significa sustancialmente tres cosas, que juegan siempre en toda afirmación concreta de una libertad. Exención o independencia o autonomía, por la que se constituye una esfera de autonomía privada, de decisión personal o colectiva protegida frente a presiones que puedan determinarla; poder hacer, esto es, capacidad positiva, para llevar a cabo esas decisiones y actuar eficazmente en la vida social; libertad de elección, entre hacer o no hacer, o entre varios haceres posibles" ${ }^{34}$.

29 Lo señala D. Llamazares, que ha prestado atención al tema de la influencia en el Derecho constitucional español de los Tratados internacionales sobre derechos humanos, en su Derecho eclesiástico del Estado. Derecho de la libertad de conciencia, Madrid, 1989, págs. 191-195.

${ }^{30}$ "Pocas nociones de la filosofía jurídica ofrecen una gama de significados tan plurales como la libertad" (L. Prieto Sanchis, op. cit., pág. 184).

31 C. Rossiter, The Pattern of Liberty, Cornell U.P. 1958, cit. por L. SANCHEZ Agesta, Sistema político de la Constitución española de 1978, 6. ed., Madrid, 1991, pág. 122.

32 L. SÁnChez Agesta, op. cit., pág. 121.

33 L. Sánchez Agesta, op. cit., pág. 122.

34 L. SÁnChez Agesta, op. cit., pág. 122. Los subrayados son del autor. 
Se enriquece esta idea con la consideración de PECES-BARBA, que pone en relación la libertad y los restantes valores superiores recogidos en el texto constitucional con la función de justicia que a la propia Constitución corresponde. "Por la función de justicia -escribe-, la Constitución establece los valores superiores, y así los denomina el artículo 1.1, los principios éticos que dirigen y explican los objetivos máximos del Ordenamiento Juridico"; "la función de justicia expresa la recepción en la Constitución de valores éticos que el poder democrático asume como propios y los convierte en valores políticos. Son los que SCHMITT llama decisiones políticas fundamentales, que el poder constituyente traslada a la Constitución como valores jurídicos» ${ }^{35}$.

La idea de libertad se nos aparece, pues, como un valor ético que deviene un valor político. Ello supone que se trata de un valor universal ${ }^{36}$; en primer lugar, porque toda ética trata de serlo $y$, en segundo, porque la Constitución ha de operar con valores éticos universales, no con los propios de una confesión religiosa o de una ideología limitadas, que dejase fuera de la libertad a una parte de los destinatarios de la norma constitucional. No tendría, en otro caso, sentido, la remisión del artículo 10 a la Declaración Universal de Derechos Humanos ${ }^{37}$; y no porque ésta lleve en su titulación el adjetivo de universal, sino porque los valores recogidos en el artículo 1.1 han de responder a la idea universal de Estado democrático ${ }^{38}$, con proyección en todo el mundo en el presente momento de la Historia ${ }^{39}$.

Tal condición de universal del valor ético de la libertad en un contexto democrático supone que necesariamente el valor político que la Constitución acoge es expresión de aquél. En consecuencia, en la situación de pacífica y libre convivencia social y política que la Constitución instaura y preside, la libertad ha de reconocerse a todos. La universalidad no puede ser tan sólo una condición de teórica aplicabilidad a toda so-

35 G. Peces-Barba, "Prólogo» al vol. La Constitución Española de 1978, Madrid, 1990, pág. 14.

${ }_{36}$ Vid. las consideraciones sobre la universalidad, no solamente en el espacio sino también en el tiempo - «el derecho de libertad de conciencia es, en última instancia, el verdadero protagonista de nuestra historia»-, que hace D. LLAMAZARES en su op. cit., págs. 13-14.

${ }^{37}$ Ha llamado sobre ello la atención J. Ferrer Ortiz, "Los principios constitucionales del Derecho eclesiástico como sisteman, en VV.AA., Relaciones entre la Iglesia y el Estado, cit., pág. 315.

${ }_{38}$ Así lo subraya D. Llamazares, op. cit., pág. 16.

${ }^{39}$. Una muestra de la recepción en Europa del principio de la libertad, y en concreto de la libertad religiosa, nos la ofrece C. CoRRal Salvador, La libertad religiosa en la Comunidad Económica Europea, Madrid, 1973. 
ciedad democrática del valor de la libertad ${ }^{40}$, sino un efectivo reconocimiento de que éste corresponde como derecho propio a todos y cada uno de los ciudadanos. Como veremos enseguida, los límites de la libertad son los límites de la justicia, que ya la Romanidad había definido con la trilogía del uhonestum vivere, alterum non laedere, ius suum cuique tribuere».

\section{b) Libertad e igualdad}

Pero subráyese además que el segundo valor recogido en el artículo 1.1 es el de la igualdad. En principio, la igualdad tendría que entenderse como la misma libertad para todos ${ }^{41}$.

Por otra parte, el principio romano que acabamos de recordar no supone un igual derecho para todos, sino "su" derecho para cada uno, y los derechos no pueden ser ni son todos los mismos. La polémica en torno al sentido de la igualdad y a la relación de ésta con la libertad es clásica en la doctrina ${ }^{42}$. Resulta axiomática la afirmación de que no se puede tratar igual a los desiguales, pues en tal "summum ius" se escondería una "summa iniuria" ${ }^{43}$. Pero no es menos cierto que mediante la proclamación de la primacía de la libertad sobre la igualdad, que sería la posición opuesta, se puede asimismo incidir en notorias injusticias, que eliminarían de hecho el papel en el ordenamiento del princi-

40 "La libertad de conciencia no es sólo una utopia, es una utopía cierta y definida y, aunque parezca paradoja, alcanzable" (D. LlamazareS, op. cit., pág. 13).

${ }^{41}$ "La no autonomía de la igualdad con respecto a la libertad aparece así expresada netamente: los hombres han de ser iguales en la libertad" (A. DE LA HERA, Pluralismo y Libertad Religiosa, Sevilla, 1971, pág. 32); "lo que el ordenamiento jurídico persigue no es la igualdad o la libertad por separado, sino la igualdad de todos los ciudadanos, no sólo en la titularidad, sino también en el ejercicio de la libertad. Se trata de un solo derecho y de un solo principio: Igualdad en la libertad" (D. Llamazares, op. cit., pág. 651).

${ }_{42}$ "Ambos derechos reclaman un respeto absoluto, que en ocasiones es imposible concederle a uno sin lesionar las exigencias del otro" (A. DE LA HERA, op. cit., pág. 46). Vid. asimismo F. ONIDA, Uguaglianza e libertà religiosa nel separatismo statunitense, Milano, 1970, págs. 11-12, con la abundante bibliografía allí citada.

43 "La equidad exige tratar igualmente lo igual y desigualmente to desigual"; "lo incompatible con el mandato del artículo 14 no es cualquier desigualdad, sino sólo la no susceptible de justificación razonable suficienten (D. LLAMAZARES, op. cit., pág. 652). 
pio superior - valor ético transformado en valor jurídico- de la igualdad $^{44}$.

La doctrina ha insistido en todo caso en la idea de que "la libertad es el auténtico valor superior. Los demás enunciados por el artículo 1.1, v otros que puedan añadírsele, son derivados de la libertad» "4. "Por su parte, la igualdad es un concepto relacional, una simple ecuación entre dos cosas o magnitudes que se comparan y que pueden ser o no valiosas. En efecto, la igualdad no es nada en sí. Hace falta saber en qué o de quién hay o no igualdad... Lo valioso está en lo que se compara, no en la comparación, que es, como digo, simple ecuación, concepto matemático, ente de razón. Lo valioso está en esos derechos y bienes, no en la igualdad con que los tenemos o carecemos" ${ }^{46}$. Pues bien, aun partiendo de este concepto de la igualdad, el valor que la vigente Constitución española proclama y que se reconoce como supremo ${ }^{47}$, el de la libertad, sería y es incluso lo verdaderamente valioso, y valga la redundancia. La igualdad con que lo poseemos supone entonces el grado de libertad que cada ciudadano posee y que ve reconocido $y$ tutelado por el ordenamiento ${ }^{48}$. ¿Cuál debe ser ese grado?

\section{c) Libertad, igualdad y justicia}

Entra aquí en juego el tercer valor superior del ordenamiento, la justicia. También para TORRES DEL MORAL estamos ante un valor rela-

44 «La igualdad religiosa ante la ley no tiene nada que ver con la uniformidad. Significa que forma parte del común y radical patrimonio jurídico del ciudadano español la titularidad, en igualdad de calidad y trato ante la ley, del derecho de libertad religiosa. Con independencia de cualquier circunstancia, al margen del signo de sus convicciones religiosas, sólo por ser ciudadanos, todos los españoles tienen en su patrimonio jurídico el mismo derecho fundamental de libertad religiosa» (P. J. VILADRICH, op. cit., pág. 225).

45 A. Torres del Moral, Principios de Derecho Constitucional español, 3.a ed., Madrid, 1992, pág. 50.

${ }_{46}$ A. TORRES DEL Moral, op. cit., págs. 50-51.

47 Vid. L. SÁnchez Agesta, op. cit., págs. 122-123.

48 L. SÁnCHEZ AGESTA señala con precisión la dimensión social de la libertad, que evita que la «esfera de libertad pueda a su vez parecer propicia a la realización de un individualismo", dimensión en la que juega el principio de igualdad como base de la "sociabilidad inherente al desenvolvimiento y perfección de la personalidad", que implica "la solidaridad de la vida comunitaria". "Libertad personal -añade el mismo autor - significa, desde luego, autonomía, poder y capacidad de opción de la persona, pero también significa al mismo tiempo respeto y cooperación para realizar el derecho ajeno, servicio y lealtad a una comunidad y al orden en que se articula el bien público, como prestación de las condiciones para la libertad efectiva de todos y cada uno" (op. cit., págs. 123-124). 
cionado con la libertad, del mismo modo que sucede con la igualdad. "Con la justicia, tan cercana a la igualdad, ocurre otro tanto. Lo que deseamos y valoramos es lo que nos falta injustamente. $Y$ lo que reclamamos, en realidad, no es justicia, sino los derechos y bienes que nos faltan y que consideramos nuestros o que se nos deben. La justicia se nos erige como valor, lo mismo que la igualdad, mediante un proceso (legítimo) de abstracción" ${ }^{49}$.

Entiendo que lo que con estas palabras quiere expresarse es que igualdad y justicia son valores instrumentales, sin los cuales no se puede garantizar el disfrute de la libertad. La libertad solamente será un valor superior del ordenamiento, siendo el valor supremo de origen ético capaz de presidir un ordenamiento jurídico, si el propio ordenamiento está en condiciones de garantizarla a todos los titulares de tal derecho fundamental de la persona. No todos precisarán, en función de sus circunstancias personales ante el ordenamiento, de la misma libertad; pero todos precisarán de la máxima libertad que necesiten y les corresponda como derecho. Ése es el sentido de la igualdad de todos ante la ley, y en consecuencia de la consideración de la igualdad como un valor superior del ordenamiento. Si no figurase la igualdad en tal posición dentro del texto constitucional, la libertad se convertiría en una entelequia, una proclamación de derechos sin verdadera efectividad real. En este sentido se ha dicho que la libertad no es posible sin la igualdad ni ésta sin aquélla. "La igualdad y la libertad en cuanto principios informadores y en cuanto derechos subjetivos, han sido con frecuencia entendidos como escindibles e, incluso, al menos ocasionalmente, como contradictorios. De ahí que en algunos modelos del Derecho comparado se subordinara el uno al otro (la libertad a la igualdad en el francés, o ésta última a la primera en el alemán). Se trata de dos derechos subjetivos y de dos principios fundamentales inseparables; en tanto que valores a realizar por el ordenamiento, no son posibles el uno sin el otron ${ }^{50}$.

$Y$ el mismo valor instrumental, en su esfera, posee entonces la justicia ${ }^{51}$. Un recorte ilegitimo de la libertad, o una limitación indebida de la igualdad, suponen una infracción de la justicia, una situación injusta ${ }^{52}$. Al

${ }^{49}$ A. Torres del Moral, op. cit., pág. 51.

50 D. Llamazares, op. cit., pág. 651.

51 «En esa dialéctica de creación y aplicación del Derecho, junto a la cadena de validez de las normas, que se fundamenta en la autoridad y en la habilitación de las superiores normas de producción, respecto de las inferiores que son de ejecución, y así sucesivamente, y que es un criterio formal, el kelseniano de la construcción gradual del ordenamiento, existe una cadena de justicia que supone el progresivo desarrollo de esos valores superiores" (G. PECES-BARBA, op. cit., pág. 14).

52 "¿Qué significa la igualdad junto a la justicia y, por tanto, distinta de ésta? Probablemente una idea más o menos vaga de igualdad de hecho" (S. BASILE, 
mismo tiempo, la consecución de la justicia es un objetivo o tal vez sea mejor decir el objetivo supremo del Derecho. Y la justicia, en cuanto instrumento de acción del ordenamiento, garantiza la efectividad de la libertad y la igualdad. Es justo que los hombres vean tutelado su derecho a la libertad y a la igualdad, y consiguientemente cabe señalar la justicia como un valor superior del ordenamiento.

\section{d) La función de justicia de la Constitución}

Sin embargo, no debe descuidarse el hecho de que una afirmación de PECES-BARBA, recogida más arriba y coherente con una notoria dirección doctrinal entre los intérpretes de la Constitución, requiere una explicación que la clarifique. Afirmaba PECES, en efecto, que "toda Constitución y también la española de 29 de diciembre de 1978 entre ellas, realiza tres funciones: la de seguridad, la de justicia y la de legitimidad" ${ }^{53}$. Y, al ocuparse de la segunda, será cuando afirme que "por la función de justicia la Constitución establece los valores superiores" ${ }^{54}$. Pero, dado que entre esos valores superiores uno es precisamente la justicia, parece esconderse una petición de principio en la idea de la función de justicia que establece el valor de la justicia.

Tal vez quepa ver claro en este punto si se recurre al artículo 117.1 del texto constitucional, primero del Título VI, "Del Poder Judicial»; "La justicia - dice- emana del pueblo y se administra en nombre del Rey por Jueces y Magistrados integrantes del poder judicial». Así cabe entender que la justicia sea un valor instrumental al servicio de la dignidad de la persona humana, garantizado por la Constitución en cuanto realidad previa a la misma, que emana del pueblo y que se actúa mediante mecanismos judiciales pero no solamente mediante mecanismos judiciales; éstos tienen la misión de hacer efectivo en último extremo el respeto a la justicia que ha de inspirar todo el ordenamiento ${ }^{55}$, siendo esta inspiración la

"Los "valores superiores", los principios fundamentales y los derechos y libertades publicas», en VV.AA., La Constitución española de 1978, estudio sistemático dirigido por A. Predieri y E. Garcia de Enterría, Madrid, 1981, pág. 272).

53 G. Peces-Barba, op. cit., pág. 12.

54 G. Peces-Barba, op. cit., pág. 14.

55 «Función de justicia de la Constitución es sinónimo de desarrollo de los contenidos materiales de la misma, y en cierto sentido, superación de la dialéctica iusnaturalismo positivismo, con el reconocimiento de una moral legalizada. Como es notorio, si se conoce la jurisprudencia del Tribunal Constitucional, la garantía de la Constitución, su preservación ante las normas inferiores alcanza a esta función 
forma primera y fundamental de actuación del principio de justicia a través de la ley suprema.

Por lo que no carece de fundamento la crítica que se ha hecho al artículo 1.1 de la Constitución por el olvido entre los valores superiores del ordenamiento de la dignidad de la persona humana, a cuyo servicio se consagra la justicia que realiza una doble función: determina el grado de libertad e igualdad a reconocer y tutelar a cada persona y proporciona los medios precisos para su real efectividad ${ }^{56}$.

\section{e) Libertad y pluralismo}

Aún se complementa la relación de valores superiores con la mención del pluralismo político. Se ha considerado que "la identificación de los valores constitucionales se entorpece también por la mención expresa que el artículo 1.1 hace del pluralismo político... cuando es, más bien, un principio político estructural a través del cual - pero no de él solose realiza el valor libertad" "57; "el pluralismo político no es en sí mismo un

de justicia" (G. Peces-Barba, op. cit., págs. 14-15). Debe sin embargo tenerse en cuenta que la existencia de una moral legalizada puede provenir de un positivismo que de hecho no sólo no haya superado su dialéctica con el iusnaturalismo, sino que haya pasado por encima de ella. También se ha dicho por la doctrina, haciendo eco de la dificultad de concretar a través de los Tribunales una realización plena de los valores superiores del ordenamiento, que "aun admitiendo que estos "valores superiores" tengan un significado de alguna manera precisable, puesto que se trata de "valores" y puesto que entre los "valores" se establecen, por regla general, órdenes de prioridad... se trataría de entender entre otras cosas qué es lo primero: la libertad, la justicia, la igualdad o el pluralismo político. ¿O es que quizá el orden de prioridad obedece al orden en que han sido escritos en la fórmula del artículo 1.? El Tribunal Constitucional español, en el caso de que quisiese seguir al Tribunal alemán en el tema de la jerarquía de los valores constitucionales, recibiria de las indicaciones del artículo 1. un fuerte apoyo para emprender este camino, pero nada más" (S. BASILE, op. cit., págs. 272-273).

${ }_{56}$ "El constituyente, sin embargo, ha igualado la libertad con los demás valores superiores, ha incluido dentro de ellos al pluralismo político y ha excluido la dignidad de la persona humana. Todo ello en una pirueta difícilmente inteligible en la que este valor de la dignidad humana no goza de la misma protección constitucional que los valores del artículo $1.1 \mathrm{ni}$ que algunos derechos y libertades que son consecuencia suya y que sin ella carecerían de significado" (A. TORRES DEL MORAL, op. cit., pág. 51).

57 A. Torres del Moral, op. cit., pág. 51. Por su parte, escribe S. Basile (op. cit., pág. 272): “El "pluralismo político", evidentemente, no puede ser una simple aspiración ideal ni, en sentido propio, algo que deba propugnarse: será o no será 
valor sino un resultado - valioso, eso sí- de la libertad, al tiempo que un eficaz medio de defender $e$ incrementar esa libertad $"{ }^{58}$.

Quizás esta visión del que la Constitución considera cuarto valor superior del ordenamiento esté muy mediatizada por el texto del artículo 6 de la propia norma suprema, según el cual "los partidos políticos expresan el pluralismo político". Éste, como valor superior del ordenamiento, se recoge sin duda en el artículo 6 en uno de sus aspectos, pero no se agota en él; los partidos no son la única expresión posible del pluralismo político, que reducido a la idea literal que en sí parece contener la expresión ha sido objeto de una severa crítica -en relación con su presencia en el artículo 1. - - por parte de la doctrina ${ }^{59}$. Supone tal valor la aceptación de la pluralidad de opiniones sobre la convivencia social que abarca los aspectos todos de la vida humana, incluidos los religiosos ${ }^{60}$. No solamente es el hombre titular de un derecho a la libertad, sino que éste se actúa mediante la igualdad de todos ante la ley, la garantía de que la atribución de la libertad se hará con justicia - dar a cada uno lo suyo-y de que esa misma libertad supone la discrepancia de pareceres hasta sobre la realidad misma de la libertad gozable por cada ser humano en el marco de la convivencia en la "polis", en la vida social y política.

\section{LOS ACUERDOS CON LA SANTA SEDE DE 1979}

Obviamente, en este marco constitucional no cabía mantener el régimen de libertad religiosa heredado del sistema político precedente, tal

un aspecto de la realidad político-institucional que, de por sí, no depende sólo del Derecho y que, por lo que se refiere al Derecho, depende de él sólo bajo el perfil de la garantía de ciertos derechos tradicionales de libertad. Una vez asegurados estos derechos, la obligación del Estado respecto al "pluralismo político" se ha agotado, $\checkmark$ no hay nada que "propugnar"".

58 A. TORRES DEL MORAL, op. cit., pág. 51.

59 Vid. S. BASILE, op. cit., págs. 266 y ss., con las referencias allí contenidas.

so "La necesidad de una libertad creadora de pluralismo conduce a que mientras en la titularidad de los derechos no puede haber diferenciación, en el terreno de su ejercicio, naturalmente, cada sujeto se manifiesta según su libre, propia y singular particularidad, de donde la igualdad radical, como sujeto de derecho, se traduce en el orden social de una convivencia pluralista. Este principio de igualdad, de otra parte, tenemos que referirlo a la concepción integral de la libertad religiosa, que con sus luchas y rechazos siempre se ha manifestado de múltiples formas" (J. Goti Ordeñana, Sistema de Derecho eclesiástico del Estado, Donostia, 1991, pág. 276). 
como ha quedado descrito líneas arriba ${ }^{61}$. La existencia de una doble regulación, una por vía ajena a la Ley de Libertad Religiosa, en favor de la Iglesia católica, y otra notablemente más restrictiva para el resto de las confesiones en el ámbito de dicha Ley, suponía una clara contradicción con el artículo 1.1 de la Constitución ${ }^{62}$; de haber éste limitado su enumeración de los principios superiores a la libertad, hubiese cabido mantener aquellas diferencias entre la libertad religiosa reconocida por la Ley de 1967 y la establecida para la Iglesia católica por vía concordataria y a través de las Leyes Fundamentales ${ }^{63}$; pero precisamente la mención en el texto constitucional de la igualdad, la justicia y el pluralismo, en el sentido que hemos procurado exponer líneas arriba, marcaba una exigencia que solamente a través de una nueva legislación podría plasmarse.

De hecho, y sin embargo, simultáneamente con la elaboración de la Constitución negoció el Estado español con la Santa Sede la sustitución del Concordato de 1953.

Ya en 1976, pocos meses después de la muerte del General Franco y de la consiguiente instauración de la Monarquía, uno de los primeros actos del Gobierno Suárez ${ }^{64}$ había sido la firma de un Acuerdo con la Santa Sede, que modificaba en varios puntos al Concordato ${ }^{65}$. Este primer Acuerdo no afectó al tema de la libertad religiosa, no tocando a ésta ninguno de los puntos que contenía ${ }^{66}$. Pero supuso ya un anuncio de la voluntad del nuevo régimen para cambiar sustancialmente las bases de la política religiosa, puesto que entrañaba la interrupción de un sistema de estrecha enfeudación mutua entre la Iglesia católica y el Estado: el

61 Vid. sobre el proceso de transición A. Motilla, op. cit., págs. 30 y ss.

${ }_{62}$ Vid. P. Lombardía, «Precedentes del Derecho eclesiástico español", cit. págs. $130-131$.

63 Naturalmente, siempre que se admitiese la posibilidad de un concepto autónomo de la libertad al margen de la igualdad, olvidando el peligro de individualismo insolidario a que tal concepto conduciria y que ya vimos que era señalado por L. SánChez Agesta (op. cit, pág. 123), y olvidando asimismo las indicaciones -que recogíamos más arriba- de D. Llamazares (op. cit., pág. 651) sobre la igualdad en la libertad.

${ }_{64}$ "Es nuevamente necesario subrayar el dato significativo del fulgurante acuerdo de voluntades entre la Iglesia y el Estado que se produce en el primer Gobierno presidido por Suárez" (A. Motilla, op. cit., pág. 39).

${ }_{65}$ "Bastaron tres semanas para que se firmara el Acuerdo de 1976, primer peldaño en la sustitución del Concordato de 1953 por un régimen jurídico que se adecuara a lo que entendían las partes eran las nuevas circunstancias sociales y eclesiales" (A. MotiLlA, op. cit., pág. 39).

66 Vid. sobre el contenido del Acuerdo A. DE LA HERA, "Comentario al acuerdo entre la Santa Sede y el Estado Español de 28 de julio de 1976", en lus Canonicum, XVI, 1976, págs. 153-163. 
Acuerdo de 1976 suprimió precisamente dos de los privilegios que gozaban de una más larga tradición -muchos siglos- en nuestro ordenamiento: el derecho de presentación ${ }^{67}$ y el privilegio del fuero ${ }^{68}$. A partir de ese momento, la tutela del Estado sobre la Iglesia fue mucho menor, y se anunciaba un verdadero sistema de separación, que hubo de llegar en 1979 , y que resultaba mucho más coherente con la no confesionalidad del Estado proclamada por la Constitución al establecer cuáles iban a ser los principios superiores del sistema jurídico ${ }^{69}$.

Entre 1976 y 1978 subsiste el Concordato, cuyo carácter obsoleto no se le oculta sin embargo a nadie ${ }^{70}$. Si duras habían sido las críticas al mismo en los últimos años del régimen franquista -incluso provenientes de juristas de probada ortodoxia católica y de un importante sector de canonistas, así como de significados representantes de la propia jerarquía y el clero-7", las mismas se hicieron generales bajo la Monarquía. No se trataba ya de argumentar la incapacidad demostrada por el Concordato para resolver problemas en los años del Franquismo ${ }^{72}$, sino de explayar una realidad evidente: las bases ideológicas de la democracia parlamentaria que se quería instaurar contrastaban con determinados e importantes preceptos concordados. De ahí que ambas Altas Partes iniciasen pronto una renovación de sus relaciones que ya anunció el Acuerdo de 1976; la correspondiente negociación condujo a la sustitución del Concordato por una serie de Acuerdos parciales, monotemáticos, que es-

67 Vid. al respecto, en relación con el Acuerdo de 1976 y la renuncia al privilegio de presentación, T. García BARBERENA, "Nombramiento de obispos", en VV.AA. (dirección, C. CORRAL y L. DE ECHEVERRIA), Los Acuerdos entre la Iglesia y España, Madrid, 1980, págs. 129-139.

68 Sobre este punto del Acuerdo de 1976, vid. F. LoDos, "Renuncia al privilegio del fuero", en VV.AA., Los Acuerdos entre la lglesia y España, cit., págs. 141-152.

69 Vid. las observaciones, seguidas luego por buena parte de la doctrina, que hace P. J. VILADRICH sobre la no confesionalidad y el principio de laicidad del Estado español a raiz de la Constitución de 1978, en su op. cit., págs. 214 y ss.

${ }_{70}$ "Después de la celebración del Concilio Vaticano II el Concordato de 1953 entró en una situación de crisis" (P. Lombardí, op. cit., pág. 127).

" "Las dos razones más frecuentemente invocadas en el período en que se desenvolvió la crisis del Concordato fueron su falta de sintonía con la doctrina del Concilio Vaticano II y de adaptación a las nuevas circunstancias de la sociedad española" (P. Lombardia, op. cit., pág. 127).

72 "Dado que el Concordato surgió en una época de armonía entre la Santa Sede y el Estado español y que no fue concebido con ánimo innovador, su articulado se redactó reflejando la cordialidad de unas relaciones y no como norma clara, apta para resolver situaciones conflictivas. De aquí las fundadas críticas acerca de la imprevisión de algunos de sus artículos, que habrían de originar difíciles problemas de interpretación en momentos en los que las relaciones Iglesia-Estado se desarrollaron con mayor tirantez" (P. LOMBARDí, op. cit., pág. 127). 
tuvieron concluidos en 1978 a la vez que la propia Constitución ${ }^{73}$, y que hubiesen podido firmarse antes que ésta; para no hacerlo así, se esperó unos días, y promulgada la Constitución el 29 de diciembre de 1978, el 3 de enero de 1979 se procedió a la firma de los Acuerdos ${ }^{74}$.

Son éstos cuatro, como de todos es sabido, que se suman al de 1976 para constituir el conjunto de los textos pacticios que rigen hoy las relaciones Iglesia-Estado en España; y el haberse presentado bajo tal forma varios Acuerdos firmados conjuntamente- en lugar de bajo la habitual de un único concordato tratando todos los temas, fue el resultado de la tesis, que se expuso ampliamente por importantes sectores de la doctrina, de que los Acuerdos facilitaban con ventaja sobre el Concordato las relaciones de la Iglesia con el Estado en momentos de especiales dificultades para las mismas ${ }^{75}$. De hecho, la opción por un sistema de Acuerdos en lugar de por un sistema de Concordato presenta en sí misma una aparente ventaja: un Acuerdo concreto puede ser revisado o denunciado sin incidir sobre los demás; pero ¿es que sería imposible revisar parte de un concordato sin tocar el resto de sus prescripciones? Y, por otra parte, sumados los cuatro Acuerdos de 1979, más el de 1976 y uno residual de 1962 que continúa vigente y que se firmó entonces al margen del Concordato ${ }^{76}$, en realidad están de hecho cubiertas todas o casi todas las materias de mutuo interés que hubiese podido regular un Concordato ${ }^{77}$. Los Acuerdos sustituyeron al Concor-

73 Una historia detallada de la negociación que condujo a los Acuerdos, en J. M. Diaz Moreno, "Historia del Texto", en VV.AA., Los Acuerdos entre la Iglesia y España, cit., págs. 79-95.

74 Publica los Acuerdos, acompañados de documentación sobre los mismos, C. Corral en el cap. XXIX, "Textos oficiales", de la obra de VV.AA., Los Acuerdos entre la lglesia y España, cit., págs. 777-810.

${ }_{75}$ Vid. al respecto, entre otros muchos autores, J. GIMÉnEZ y MARTínez DE CARVAJAL, "Los concordatos en la actualidad", en VV.AA., Derecho Canónico, cit., págs. 755-760, con la bibliografía que alli se recoge.

${ }_{76}$ Se trata del Convenio del 5 de abril de 1962, que regula la eficacia de los estudios civiles que se realizan en universidades eclesiásticas; puede verse sobre el mismo A. DE FuENMAYOR, El Convenio entre la Santa Sede y España sobre universidades de estudios civiles, Pamplona, 1965.

77 Con la firma de los Acuerdos «queda resuelta la antigua polémica acerca de si el Concordato de 1953 debía ser sustituido por un nuevo Concordato o por una pluralidad de acuerdos. Formalmente se da la razón a los sostenedores de la última tesis, pues es evidente que nos encontramos ante una pluralidad de textos normativos; pero hay que conceder que una pluralidad de acuerdos, negociados simultáneamente, firmados $y$ ratificados en la misma fecha, y que pretenden regular la totalidad de las cuestiones Iglesia-Estado, es algo que se parece extraordinariamente a un Concordato... La unidad de un Concordato o de un Código no se deriva de la unidad de documento o de cronología, sino de la temática y la normativan (I. C. IBÁN, "El sistema de fuentes del Derecho eclesiástico", en I. C. IBÁN, L. Prieto SANCHIS, A. MotILLA, op. cit., pág. 149). El mismo parecer en J. Fornes, El nuevo sistema concordatario español (Los acuerdos de 1976 y 1979), Pamplona, 1979, pág. 17. 
dato en un clima de laicismo estatal y separación Iglesia-Estado, salvando la posibilidad del entendimiento entre las dos Partes por una vía no simplemente fáctica; su perfección técnica no es en cambio superior a la del Concordato de 1953, y probablemente es inferior.

\section{EL NUEVO ORDEN CONSTITUCIONAL}

\section{a) La situación creada por la Constitución y por los Acuerdos con la Santa Sede}

La situación, pues, a partir de enero de 1979, es la siguiente: a) la Constitución, sin proclamarlo con palabras expresas, establece un laicismo de Estado abierto a la cooperación con las confesiones religiosas; b) y ello sobre la base de los principios de libertad e igualdad, que suponen un trato justo a las plurales opiniones y actitudes religiosas de los ciudadanos. Pero, al mismo tiempo, el artículo 16.3, a la vez que establece que "ninguna confesión tendrá carácter estatal", obliga a los poderes públicos a tener en cuenta "las creencias religiosas de la sociedad española" y asimismo a mantener las "consiguientes relaciones de cooperación con la Iglesia Católica y las demás confesiones". Es lo que la doctrina ha calificado como los uprincipios constitucionales del Derecho Eclesiástico español", y que son el principio de libertad religiosa, el principio de aconfesionalidad y el principio de cooperación ${ }^{78}$.

La propia redacción del texto constitucional, en cuanto que le dedica una especial mención, supone ya el mantenimiento de una diferencia entre la Iglesia católica $y$ el resto de las confesiones religiosas con adeptos en España ${ }^{79}$. Y, como ha quedado dicho, el 3 de enero de 1979, apenas unos días tras la entrada en vigor de la Constitución, el Estado y la citada Iglesia firmaron los Acuerdos que, por el momento, suponían una situación jurídica distinta, en nuestro ordenamiento, para la confesión religiosa mayoritaria en el país ${ }^{80}$.

${ }_{78}$ Vid. particularmente P. J. VILADRICH, op. cit, págs. 193 ss.; F. DE P. VERA URBANO, op. cit., pág. 286.

${ }_{9}$ Vid. al respecto A. Bernárdez Cantón, "La mención de la lglesia católica en la Constitución españolan, en VV.AA, Relaciones entre la lglesia y el Estado, cit., págs. 403-420; P. J. VILADRICH, epigrafe "La mención explícita de la Iglesia católica en la Constitución", op. cit., págs. 230-234.

${ }_{80}$ Subraya aún esa singularidad de los Acuerdos I. C. IBÁN, op. cit., págs. 148-149, al escribir: "Hay que tener en cuenta la fecha de la firma de los Acuerdos 
No entraremos aqui en la cuestión de las razones por las que esta Iglesia fue objeto de una mención especial en la norma suprema, pues ya la doctrina ha analizado suficientemente el tema ${ }^{81}$. Pero sí hemos de subrayar que tal mención no podía suponer por sí misma una mayor libertad para la Iglesia católica, con merma del principio de igualdad en relación con las demás confesiones ${ }^{82}$. El Estado, a través del artículo 16.1, se comprometía a mantener relaciones de cooperación con todas las confesiones religiosas existentes en el país; que al mencionarlas se señale a una distinguiéndola de las demás puede obedecer a motivos históricos, sociológicos, etc., pero no suponer una ruptura de las exigencias del artículo 1.1 de la propia norma suprema. En todo caso, y sin pretender obtener aquí mayores consecuencias de ello, el principio superior de la justicia - no menos inspirador del ordenamiento que los de libertad, igualdad y pluralismo-sí que podía exigir esa mención de la Iglesia católica, cuya presencia en el país y cuyas posibilidades de cooperación con el Estado se multiplican por cifras altísimas si la compara-

en 1979: éstos son firmados apenas una semana después de la entrada en vigor de la Constitución, lo cual significa que como quiera que en la ratificación parlamentaria de los mismos no se alteró ni tan siquiera mínimamente su contenido como, por otra parte, establece el procedimiento parlamentario previsto para la aprobación de tratados internacionales-, el pretender que los Acuerdos son un desarrollo del principio de cooperación previsto en el art. 16 de la Constitución no sería sino la adopción de una postura rígidamente formalista que, inevitablemente, llevaría a realizar un análisis equivocado de sus resultados". Tesis discutible, puesto que un texto incluso previo a la Constitución -que no es el caso, al menos formalmente-, "praeter constitutionis" (como llama el propio lBáN, pág. 149, a los Acuerdos), puede ser aceptado por el Parlamento precisamente porque su contenido suponga un desarrollo o aplicación de un principio constitucional, habiendo el propio Parlamento podido rechazar en bloque los Acuerdos, negándose a ratificarlos, de haber considerado que no podian ser encajados en el desarrollo constitucional del mismo modo que otros Acuerdos posibles posteriores a la Ley suprema.

${ }^{81}$ Vid. la obra de A. BERnÁRDEZ CANTÓN, cit., que ofrece además bibliografía al respecto; de interés también J. M. GonzÁlez DEL VALLE, «Posición jurídica de las confesiones religiosas", en J. M. GonZález del VALLE y otros, Derecho eclesiástico del Estado español, cit., págs. 287-298. Asimismo los epigrafes "La mención de la Iglesia Católica y la no confesionalidad del Estado» y «La mención de la Iglesia Católica como paradigma extensivo de trato especifico a las demás confesiones", en la op. cit. de P. J. VILADRICH, págs. 231-234.

82 "Nos queda ahora por resolver si nuestra Constitución, al mencionar a la Iglesia católica de forma explícita, rompe el principio de igualdad con las demás confesiones, consagrando paradójicamente en el texto constitucional una discriminación por motivos religiosos, o si, en realidad, estamos ante una muestra perfectamente constitucional del trato específico que impone el principio de laicidad para la situación real del factor religioso católico" (P. J. VILADRICH, Op. cit., pág. 234). El autor, a través de una brillante argumentación, se inclina por la segunda hipótesis. 
mos con cualquier otra confesión ${ }^{83}$. Y si sería injusto negarle a ninguna otra confesión la libertad, no lo sería menos pretender que los presupuestos y consecuencias de sus relaciones con el Estado pueden ser idénticos a los de la confesión mayoritaria, dados los índices que señalan el significado numérico, histórico, cultural, etc., de la presencia del catolicismo en el país ${ }^{84}$.

Lo que no podía hacerse era dejar la situación en la forma en que la determinan el texto constitucional y los Acuerdos de enero de 1979; el propio texto constitucional venía a exigir de facto un desarrollo legislativo posterior en el campo de la libertad religiosa. $Y$, por supuesto, tales nuevas normas de desarrollo de la norma suprema habian de suponer la sustitución de la obsoleta Ley de Libertad Religiosa de 1967, incompatible ya con el ordenamiento constitucional ${ }^{85}$.

\section{b) La nueva Ley de Libertad Religiosa de 1980}

La nueva Ley de Libertad Religiosa, que se elaboró en consecuencia, es «la segunda gran fuente constitutiva de carácter general del Derecho eclesiástico español» " "Cronológicamente aparece, pues, con posterioridad a la Constitución, de cuyo art. 16 viene a ser un desarrollo en

83 «El inciso "... y mantendrán las consiguientes relaciones de cooperación con la Iglesia Católica y las demás confesiones" ha de interpretarse, en lo tocante a la mención de la Católica a diferencia de la genérica alusión al resto de las confesiones, como un ejemplo - ciertamente constitucional, con todo lo que ello supone- de trato específico, en atención a la enorme extensión sociológica, tradición y arraigo históricos, y complejidad orgánica y jurídica de la Iglesia católica en comparación con las demás confesiones religiosas" (P. J. VILADRICH, op. cit., p.. 234-235).

${ }^{84}$ "En el texto constitucional este trato específico se limita, en realidad, a la mención singular de la Iglesia Católica, a aludirla "con su apellido propio". Sin embargo, debemos indicar que con respecto al contenido, en que debe concretarse ese trato especifico, no hay mandato constitucional alguno como no sean las "consiguientes relaciones de cooperación", las cuales también se predican para todas las demás confesiones" (P. J. VILADRICH, op. cit., pág. 235).

${ }_{85}$ "Desde el principio de la transición política, en las nuevas coordenadas sociales, estaba la preocupación de elaborar otra Ley de libertad religiosa, que sustituyera a la de 28 de junio de 1967, y que, por lo mismo, resultaba inadecuada al pluralismo ideológico comúnmente aceptado por las Cortes y aparecía como discriminatoria para las otras iglesias y confesiones" (F. de P. Vera Urbano, op. cit., pág. 295).

${ }_{86}$ F. de P. Vera URbano, op. cit., pág. 295. 
forma de ley orgánica, y a los Acuerdos con la Santa Sede (1976, 1979). Sin embargo, es contemporánea a ellos en su preparación, pues ya el 2 de julio de 1978, previa consulta a las diversas confesiones religiosas no católicas, el Ministerio de Justicia habia establecido en consenso con estas instituciones las Bases para una nueva ley de libertad religiosa" ${ }^{87}$.

No deja de ser interesante la noticia sobre el modo de gestionar las bases para la futura ley, en cooperación exclusivamente con las confesiones no católicas. Es cierto que, al mismo tiempo, se negociaba con la Santa Sede para la sustitución del Concordato de 1953 por los Acuerdos de $1979^{88}$; resulta interesante constatar, pues, la existencia de dos negociaciones paralelas, con la Iglesia católica para los Acuerdos, con las demás confesiones para la Ley de Libertad religiosa. ¿Hay que entender en el Estado una voluntad de llevar a una y otras instituciones por caminos diferentes, consagrando el diverso tratamiento dado a una y otras anteriormente? ¿Se pensó en una Ley de Libertad religiosa que no afectase a la Iglesia católica?

Cierto que ello no hubiese supuesto necesariamente una diferencia en el grado de libertad reconocida a una y otras confesiones, ni tampoco un quiebro de la igualdad, pues la igualdad como principio superior del ordenamiento no supone igualdad en los medios o en los métodos, sino en los resultados. Pero, en todo caso, es claro que si se trabajaba con cada grupo de confesiones - la Iglesia de un lado, las demás de otroseparadamente en orden a elaborar los instrumentos legales de reconocimiento y tutela de la libertad, se corría el peligro de establecer cotas distintas en la libertad alcanzada y formas diferentes para alcanzarla, y en esta vía no hay una ruptura de la igualdad, pero sí al menos un peligro de ruptura.

¿Cuál fue la consecuencia inmediata de este "modus agendi»? La Ley de Libertad religiosa se estableció "como fuente única general para la reglamentación estatal del fenómeno social religioso; aplicable, por igual, a la Iglesia católica y a las otras iglesias, confesiones o comunidades religiosas. Si bien, a la hora de establecer un estatuto jurídico propio de cada una de ellas, por exigencia del principio de igualdad jurídica... y

${ }^{87}$ F. de P. Vera URBano, op. cit., pág. 295. Abundante información sobre el iter de la LOLR la hemos ofrecido en M. J. CIÁURRIZ, op. cit,, passim.

${ }_{88}$ Información al respecto en la op. cit. de J. M. Díaz Moreno, págs. 79 y ss., en especial 93-94; sobre los precedentes, A. MAROUINA, "Introducción historico-jurídica" al vol. de VV.AA., Los Acuerdos entre la Iglesia y el Estado en España, cit., págs. 5-31. También de sumo interés los datos que ofrece A. MotILLA DE LA CALLE, Los Acuerdos entre el Estado y las Confesiones religiosas en el Derecho español, cit., págs. 34 y ss. 
salvando siempre este marco común general, resultan en la práctica dos o más regímenes eclesiásticos distintos: uno, el de la Iglesia católica, que se concreta en los Acuerdos específicos firmados con la Santa Sede, y otro - u otros, según los casos- el de las iglesias o confesiones y comunidades religiosas no católicas que, en principio, se atienen a la normativa general de la LOLR y de la legislación complementaria a la misman ${ }^{89}$.

\section{c) Un régimen común para todas las Confesiones?}

La voluntad de la LOLR de crear un único régimen común a todas las confesiones es de por sí evidente. Como he dicho en otra ocasión, "la ley, al desarrollar el art. 16 de la Constitución, debia establecer un régimen jurídico coherente con ellos, $y$, en especial, con el principio de igualdad religiosa de todos los individuos y confesiones. Fiel a este planteamiento, su articulado desarrollaba una única normativa para todas ellas, sentando unas mismas bases para su tratamiento jurídico" ${ }^{90}$. Es por otra vía, como quedó indicado líneas arriba, por donde se introdujo en el sistema la realidad del doble régimen para una y otras confesiones: por la vía de los Acuerdos firmados con la Santa Sede, mientras - no se olvide- se negociaba la Ley de Libertad religiosa con las restantes confesiones al margen de la Iglesia católica. Vía de Acuerdos que procedía de la necesidad de tener en cuenta las peculiaridades de cada confesión, a tenor del juego de los principios de libertad e igualdad con los de justicia y pluralismo.

Sólo que los Acuerdos, que la nueva Ley va a prever ${ }^{91}$, ciertamente como medio de cooperación especifica del Estado con las confesiones ${ }^{92}$, se firmaron con la Santa Sede antes de que la Ley apareciera.

89 F. de P. Vera Urbano, op. cit., págs. 295-296. El subrayado es del autor.

so M. J. CIÁurRIZ, op. cit., pág. 94.

91 En su artículo 7.1: «El Estado, teniendo en cuenta las creencias religiosas existentes en la sociedad española, establecerá, en su caso, Acuerdos o Convenios de cooperación con las Iglesias, Confesiones y Comunidades religiosas inscritas en el Registro que por su ámbito y número de creyentes hayan alcanzado notorio arraigo en España. En todo caso, estos Acuerdos se aprobarán por Ley de las Cortes generales".

Vid. el epígrafe "Los acuerdos o convenios del artículo 7 de la L.O.L.R. como formulas de cooperación" en la obra de A. MotILLA DE LA CALLE, Los Acuerdos entre el Estado y las Confesiones religiosas en el Derecho español, Barcelona, 1985, págs. 288-291. 
Como también hemos subrayado en algún momento "la consideración del art. 7 del texto legal como marco de posteriores acuerdos entre el Estado y las confesiones religiosas - viable para la mayor parte de las confesiones- se hace insostenible en el caso de la Iglesia Católica, ya que difícilmente podía ser la ley el marco de unos acuerdos anteriores a ella» ${ }^{93}$.

Hubo incluso quien intentó, en la discusión parlamentaria de la Ley de Libertad religiosa, repetir en el artículo 7, al establecer los Acuerdos como vía de cooperación Estado-confesiones, la mención especial de la Iglesia católica que contiene el artículo 16.3 de la Constitución. Y lo querían así precisamente quienes más afines se consideraban a la ideología católica y mayor empeño habían siempre demostrado, a lo largo de todo el proceso constituyente, en legislar de acuerdo con una inspiración cristiana de la sociedad ${ }^{94}$.

No cayeron en la cuenta, quienes asi actuaban, de que en este caso hubiesen creado una situación en la cual los Acuerdos de 1979 tendrían que ser revisados a la luz de la LOLR, en lugar de mantenerse, como se mantienen, fuera del marco de la misma ${ }^{95}$. Si el artículo 7 de la LOLR, al disponer en su párrafo 1 que "el Estado, teniendo en cuenta las creencias religiosas existentes en la sociedad española, establecerá, en su caso, Acuerdos o Convenios de cooperación con las Iglesias, Confesiones y Comunidades religiosas inscritas en el Registro que por su ámbito y número de creyentes hayan alcanzado notorio arraigo en España", hubiese expresamente mencionado a la Iglesia Católica, ésta habría visto cómo sus Acuerdos previos quedaban sometidos a este artículo $y$, en consecuencia, a la totalidad de la Ley. No quiero decir que no hubiese sido positivo este hecho, pues al menos hubiese supuesto una oportunidad para revisar los Acuerdos; pero éstos son revisables en todo caso, y es obvio que ni el Estado ni la Santa Sede deseaban con ocasión de la LOLR poner en crisis el entendimiento acordado con no poco trabajo en enero de 1979. Es en todo caso evidente que la elaboración del texto de la nueva Ley adoleció de un escaso rigor técnico; «la elaboración del contenido de la ley, ignorando la vinculación a la que el Estado había quedado so-

93 M. J. CiáurRIZ, op. cit., pág. 95.

${ }_{94}$ Se contiene información sobre los intentos en este sentido durante los trámites de elaboración parlamentaria de la LOLR, en el capítulo I de M. J. Ciáurriz, op. cit., págs. 31 y ss.

${ }_{95}$ «... Defendieron fervorosamente a la Iglesia católica y concentraron sus esfuerzos en introducir en el art. 7 la mención de la Iglesia Católica como sujeto de acuerdos de cooperación con el Estado, sin darse cuenta del riesgo que dicha inclusión hubiera supuesto para la confesión mayoritaria» (M. J. CiáurRIz, op. cit., pág. 95). 
metido en temas similares mediante la firma y ratificación de los Acuerdos con la Santa Sede, originó un problema que no quedó reducido a temas meramente teóricos o cronológicos; pronto surgieron importantes contradicciones normativas en algunos aspectos concretos, siendo de destacar especialmente el de la adquisición de personalidad jurídica civil de los entes de la Iglesia Católica regulado, con carácter específico, en el Acuerdo jurídico, $y$, con carácter general, para los entes de todas las confesiones en el art. 5 de la ley. Ésta no abordaba aspectos que habian quedado regulados en el texto bilateral y, por el contrario, exigía requisitos a los que -en modo alguno- habían quedado vinculados los entes de la Iglesia Católica para adquirir reconocimiento en el ámbito civil»» ${ }^{96}$.

Lo cual permite aceptar la afirmación antes recogida de la pervivencia de un doble sistema de tratamiento de la libertad religiosa en el ordenamiento español; no ya por entender que la Iglesia Católica queda fuera de la LOLR, sino porque aún refiriéndose esta ley a la totalidad de las confesiones, la Iglesia Católica se rige además por sus propios Acuerdos con el Estado, que contienen algunas prescripciones que no encajan dentro del marco de la nueva LOLR.

Fuera de nuestro análisis debe quedar ahora la cuestión de una posible primacía de la LOLR sobre los Acuerdos Estado-Santa Sede, que resolvería el problema derogando las normas contenidas en éstos que se encuentren en contradicción con aquélla; o tal vez el de la primacía de los Acuerdos sobre la Ley, que supone lo contrario ${ }^{97}$. Razones hay en ambos sentidos, tanto por ser la Ley posterior a los Acuerdos - con juego del principio "lex posterior derogat priori»-, como por el carácter internacional de los Acuerdos, en cuya virtud no pueden ser derogados o modificados sino mediante el procedimiento especial previsto por el artículo 96 de la Constitución ${ }^{98}$.

Esta última solución viene aplicándose en la práctica, y los Acuerdos de 1979 mantienen su vigor frente a la LOLR en los puntos en que quedan fuera del marco trazado por ésta ${ }^{99}$. Tal ha sido, en efecto, la deci-

96 M. J. Ciáuraiz, op. cit., págs. 95-96.

97 Vid. el epígrafe «Problemas de encaje entre la Ley Orgánica y los Acuerdos con la Iglesia Católican, en M. J. CiÁuraiz, op. cit., págs. 95-96.

98 Vid. el epígrafe "La internacionalidad de los Acuerdos", en A. MOTILLA DE LA CALLe, op. cit., págs. 44-46.

99 Se «originó un problema que no quedó reducido a temas meramente teóricos cronológicos; pronto surgieron importantes contradicciones normativas en algunos aspectos concretos, siendo de destacar especialmente el de la adquisición de personalidad jurídica civil de los entes de la Iglesia Católica regulado, con carácter específico, en el Acuerdo jurídico, y con carácter general, para los entes de todas las confesiones, en el art. 5 de la ley" (M. J. CiÁurRIZ, op. cit., pág. 95). 
sión tomada por el Estado al promulgar la legislación de desarrollo y aplicación de la LOLR, hecho que no puede ser visto exclusivamente desde el ángulo de que se mantiene para la Iglesia católica un régimen especial al margen de la Ley de Libertad Religiosa, sino que también debe subrayarse que el Estado estaba en el deber - que desconoció- de tener en cuenta al redactar la LOLR ${ }^{100}$ los compromisos ya contraídos con la lglesia católica.

El 9 de enero de 1981 se promulgaba un Real Decreto sobre Organización y funcionamiento del Registro de Entidades Religiosas, cuyo artículo 2 dispone la inscripción en tal Registro de las Iglesias, Confesiones y Comunidades religiosas, Órdenes, Congregaciones e Institutos, entidades asociativas religiosas, y sus Federaciones ${ }^{101}$. Pues bien, una Resolución de 11 de marzo de 1982, de la Dirección General de Asuntos Religiosos del Ministerio de Justicia ${ }^{102}$, establecía un régimen especial en este terreno para la Iglesia católica y sus asociaciones, en el marco del Acuerdo de 1979 y no en el que para las restantes confesiones establecen la LOLR y el citado Real Decreto.

Por otro lado, tres confesiones religiosas han hecho ya uso de la posibilidad recogida en el artículo 7 de la LOLR, en orden a la firma de Acuerdos con el Estado: la Federación de Entidades Religiosas Evangélicas, la Federación de Comunidades Israelitas, y la Comisión Islámica de España. A lo largo de este estudio trataremos de señalar las novedades que estos Acuerdos puedan aportar al contenido de la Ley de Libertad Religiosa, dentro de cuyo marco han sido establecidos ${ }^{103}$.

100 Ya en otro lugar hemos llamado la atención sobre "la elaboración del contenido de la ley ignorando la vinculación a la que el Estado había quedado sometido en temas similares mediante la firma y ratificación de los Acuerdos con la Santa Sede" (M. J. CláurRIZ, op. cit., pág. 95).

101 Vid. el texto en M. J. CláurRIz, op. cit., págs. 256-257.

102 Hemos publicado el texto en M. J. CláuraIz, op. cit., págs. 260-261.

103 Aún es lógicamente escasa la bibliografía sobre estos tres Acuerdos. Puede verse, para los firmados con las Comunidades evangélicas $e$ israelitas, $A$. Fernández-Coronado, "Los Acuerdos del Estado español con la Federación de Entidades religiosas evangélicas de España (F.E.R.E.D.E.) y la Federación de Comunidades Israelitas (F.C.I.). Consideraciones sobre los textos definitivos", en Anuario de Derecho Eclesiástico del Estado, VII, 1991, págs. 541-577; específicamente se ocupa del Acuerdo con la Federación evangélica D. BAsterRa MonserRat, "Acuerdo Estado español-Federación evangélica», en la misma publicación, págs. 579-588. EI Acuerdo con los musulmanes, de posterior conclusión, ha sido incluido por J. A. Souto, en los comentarios que dedica a los tres Acuerdos en el "Apéndice" de su Derecho Eclesiástico del Estado, cit., págs. 541-554. 


\section{LA LIBERTAD RELIGIOSA EN LA CONSTITUCIÓN Y EN LA LEY DE 5 DE JULIO DE 1980}

\section{a) Libertad religiosa y libertad de culto}

El artículo 16 de la Constitución, que específicamente establece el derecho del ciudadano a la libertad religiosa -en desarrollo del principio capital del derecho a la libertad con que la propia Constitución se abre- menciona en su párrafo $1 .^{\circ}$ tres libertades y no solamente una: "Se garantiza - dice- la libertad ideológica, religiosa y de culto de los individuos y las comunidades". Tal dato condiciona lógicamente la reflexión sobre el sentido que en el ordenamiento español posee la liber$\operatorname{tad}^{104}$. La doctrina ha analizado hasta la exhaustividad esta frase, tratando de determinar la identidad precisa de cada libertad ${ }^{105}$, y la razón por la que el legislador constituyente eligió precisamente ésas y no otras, o ésa y no otra nomenclatura, que no coincide por otra parte con exactitud con formulaciones similares contenidas en textos internacionales $o$ constitucionales de otros paises ${ }^{106}$. Se ha preguntado la doctrina si esta-

${ }^{104}$ "La reflexión jurídica acerca de la garantía constitucional de las libertades religiosa e ideológica está lógicamente condicionada, aunque no determinada, por el propio texto de la Constitución de 1978. Tanto los juicios adversos a la oportunidad y coherencia material y formal de expresar en una misma norma realidades diferentes como los juicios que se muestran favorables a esa inclusión unitaria en el artículo 16 han encontrado un soporte racional -y dialéctico- que a cada uno puede resultar convincente" (J. CALVo, "Reflexión crítica acerca de la libertad religiosa e ideológica en la Constitución española de 1978", en VV.AA. (I. C. IBÁN, coordinador), Libertad y Derecho Fundamental de Libertad Religiosa, Madrid, 1989, págs. 117-128.

${ }^{105}$ "La Constitución española garantiza en su artículo 16 la libertad ideológica, religiosa y de culto de los individuos y de las comunidades. La mención constitucional plantea una primera cuestión: ¿se reconoce la existencia de una sola libertad con varias manifestaciones $o$, por el contrario, se garantizan tres libertades distintas? La pregunta obligaría a resolver una cuestión previa: si la libertad jurídica es única o existen tantas como calificativos se le atribuyen en los textos jurfdicos" (J. A. Souto, op. cit., pág. 79).

106 "La cuestión no es irrelevante si tenemos en cuenta que en otros textos, y muy concretamente en las declaraciones de los derechos, se menciona la libertad religiosa acompañada de otras libertades. Así, la Declaración Universal de Derechos Humanos, en su artículo 18, declara que "toda persona tiene derecho a la libertad de pensamiento, de conciencia y de religión". Como se podrá observar, las libertades que se citan aquí no son la ideológica y de culto, sino las de pensamiento y conciencia, pero, en último caso, conviene llamar la atención sobre el hecho de que la libertad religiosa se cita habitualmente acompañada de otras libertades" (J. A. Souto, op. cit., pág. 79). Tampoco a L. Prieto Sanchis le parece sin 
mos ante tres libertades distintas y autónomas entre si ${ }^{107}$; se ha especulado sobre la diferencia entre libertad religiosa y de culto, al entender que el culto no puede ser sino una manifestación de la religiosidad ${ }^{108}$; y se ha inquirido por qué falta en el texto constitucional la mención de una libertad tan clásica como es la libertad de conciencia ${ }^{109}$, tan frecuentemente citada a lo largo de la historia en toda clase de textos doctrinales y legislativos ${ }^{110}$.

La polémica o la investigación al respecto serían innecesarias en este lugar. Preciso es en cambio llegar ya al texto mismo de la Ley Orgánica de Libertad Religiosa de 1980; su propia titulación supone que el legislador trataría de desarrollar una de las tres libertades mencionadas en el artículo 16.1 de la Constitución. $Y$, sin embargo, esa primera impresión resultaría engañosa, pues la simple lectura del artículo 1 de la Ley nos va a evidenciar otra cosa: «El Estado -establece dicho artículo 1 en su párrafo 1-garantiza el derecho fundamental a la libertad religiosa y de culto, reconocida en la Constitución, de acuerdo con lo prevenido en la presente Ley orgánica».

El artículo 1 de la LOLR garantizará, pues, no una sino dos de las tres libertades mencionadas en el artículo 16.1 de la Constitución. La propia redacción de tal artículo 1 incitaría a pensar que para el legislador or-

importancia el tema: "Tras un accidentado iter parlamentario, reflejo de las propias vacilaciones del legislador, el art. 16.1 de la Constitución vino a consagrar tres libertades, la ideológica, la religiosa y la de culto, cuya diferenciación no resulta siempre fácil desde un punto de vista teórico ni aconsejable en el plano del análisis jurídico. La cuestión no carece, sin embargo, de importantes consecuencias prácticas" (op. cit., pág. 302).

107 No se trata de tres libertades distintas para J. M. González del VALLE, Derecho Eclesiástico español, cit., págs. 197-199; son diferentes en cambio para J. A. Souto, op. cit., págs. 80-84. Para D. Llamazares (op. cit., pág. 661), por lo que hace a la libertad ideológica y a la libertad religiosa, "no son idénticos los contenidos de una y otra, aunque tienen mucho en común". L. PRIETO SANCHIS (op. cit., pág. 302) entiende que «la triada del art. 16.1 forma parte de una categoría más amplia que es la libertad de pensamiento... La genérica libertad de pensamiento comprendería así las libertades ideológicas y de creencias, la de conciencia en sentido estricto, la de expresión de esas creencias y aun la de hacer prosélitos".

${ }_{108}$ "La distinción entre la libertad religiosa y de culto tiene una razón de ser preferentemente histórica, como señalamos, al tratar de la libertad religiosa como principio. Hoy día, sin embargo, se entiende que la libertad religiosa incluye, entre sus manifestaciones más típicas, la libertad de culto y que no existe un verdadero reconocimiento de la libertad religiosa, si no se reconoce igualmente la libertad de culto" (J. M. GonZález del VAlle, op. cit., pág. 197).

109 P. e., J. A. Souto, op. cit., pág. 113; D. Llamazares, op. cit., obra que precisamente bajo su título Derecho Eclesiástico del Estado aparece subtitulada Derecho de la libertad de conciencia. 
dinario -el autor de la Ley - no se trata de dos libertades, sino de una, o al menos de dos aspectos de una sola libertad ${ }^{111}$, puesto que se refiere a "la libertad religiosa y de culto", no a las libertades religiosa y de culto; pero esa interpretación olvidaría que también el articulo 16.1 emplea la palabra libertad en singular - libertad ideológica, religiosa y de cultoy que ésa es una forma habitual de expresarse en castellano.

En todo caso, la libertad ideológica queda fuera del ámbito de la LOLR, prueba a posteriori de que para el legislador se trata de libertades diferentes ${ }^{112}$. La libertad ideológica "se refiere al derecho que tiene todo ciudadano de poseer sus propias ideas y juicios sobre las distintas realidades del mundo y de la vida, es decir, una personal y libre cosmovisión» ${ }^{113}$. Sin duda alguna, la ideología desborda de por sí el ámbito de lo religioso ${ }^{114}$; una persona puede poseer una ideología y ninguna fe, de modo que su ejercicio de la libertad religiosa resulte negativo (no posee religión alguna), mientras sus opciones ideológicas resulten tan variadas como se quiera ${ }^{115}$; e incluso quien sienta profundamente una fe religiosa y entienda a través de la misma la vida y el mundo todo, tendrá ideologías de otra naturaleza, políticas, por ejemplo, o económicas, que no tienen por qué guardar relación - a lo sumo no podrían estar en contradicción-con sus convicciones religiosas.

110 "La cultura occidental, desde hace algunos siglos, se ha encontrado comprometida en la labor de hacer una adecuada diferenciación de estos tres tipos de libertades. Primeramente se inició la independencia de la libertad de conocimiento, que supuso un largo camino, con graves acusaciones a la libertad religiosa, motivada por esa confusión que se había perpetuado durante siglos. Más tarde, comienza a emanciparse la libertad de conciencia, creando una ética social independiente de la moral religiosa. Esta diferenciación exige un reconocimiento, como se hace en las formulaciones de las Declaraciones de Derechos Humanos, de tres conceptos distintos. Nuestra Constitución, sin embargo, únicamente habla de la libertad ideológica y religiosa, aunque implícitamente hay que admitir que se comprende la libertad de conciencia, como aspecto necesario de la libertad considerada en su integridad, y para evitar que haya confusión o falta de protección a uno de los derechos fundamentales" (J. Goti Ordeñana, op. cit., pág. 283).

"11 En el sentido propuesto por J. M. González del VALLE, op. cit., pág. 197: "La libertad de culto debe considerarse como un aspecto de la libertad religiosa".

112 Pueden verse las interesantes consideraciones que sobre las libertades ideológica, religiosa y de conciencia ofrece G. PECES-BARBA, "Algunas reflexiones sobre la libertad ideológica y religiosa", en VV.AA. (I. C. IBÁN, coordinador), Libertad y Derecho Fundamental de Libertad Religiosa, Madrid, 1989, págs. 53-71.

113 J. A. Souto, op. cit., pág. 80.

114 Vid. L. Prieto Sanchis, op. cit., pág. 303.

115 Vid. P. J. VILADRICH, op. cit., págs. 236-243, epígrafe «Igualdad y discriminación de creyentes y no creyentes". 
Y puesto que la Iglesia católica no se distinguirá de las demás confesiones en orden a la aplicación a la misma de esta Ley - salvo en los puntos en que sus propios Acuerdos de 1979 creen para ella un régimen especial- ${ }^{116}$, por supuesto la libertad religiosa y la libertad de culto tuteladas en la LOLR es la de todos los ciudadanos españoles, sea cual sea el ejercicio que hagan de tales libertades 0 , dicho de otro modo, la opción religiosa que prefieran. Ninguna de estas opciones - ninguna creenciapodrá constituir en España motivo de desigualdad o discriminación, ni podrán alegarse motivos religiosos para impedir a nadie el ejercicio de cualquier trabajo o actividad ${ }^{117}$ o para el desempeño de cargas o funciones públicas (artículo 1.2); y, repitiendo el texto constitucional del artículo 16.3, establece la Ley en el párrafo 3 de este artículo 1 que uninguna confesión tendrá carácter estatal», fórmula no poco criticada que fue la preferida por el legislador constituyente para señalar la no confesionalidad del Estado ${ }^{118}$, en claro contraste con la confesionalidad católica de las Leyes Fundamentales del Régimen precedente, y no poco diferente de la fórmula de no confesionalidad elegida en su día por la Constitución republicana de $1931^{19}$.

\section{b) El contenido de la libertad religiosa}

Es por su parte el artículo 2 de la Ley de 1980 el que establece la normativa relativa al contenido de la libertad que el artículo 1 garantiza. Se trata del más extenso de los artículos de la nueva Ley; posee tres párrafos, el primero de ellos subdividido en cuatro apartados, que se señalan con las letras $a, b, c$ y d. Los párrafos sustantivos son el primero y el segundo, que fijan el contenido de la norma en relación respectivamente

${ }^{116}$ Vid. P. J. VILADRICH, op. cit., págs. 234-235.

117 La relación entre derecho al trabajo e ideología religiosa la ha estudiado J. DE OTADUY, "Las empresas ideológicas: aproximación al concepto y supuestos a los que se extiende", en Anuario de Derecho Eclesiástico del Estado, II, 1986, págs. $311-332$.

${ }_{118}$ El tema ha merecido abundante bibliografía; vid. en especial P. J. VILADRICH, op. cit., epígrafe "El principio de laicidad del Estado", págs. 214 y ss., y L. PRIETO SANCHIS, op. cit., págs. 201 y ss., epígrafe «El principio de no confesionalidad del Estado".

119 «La Constitución española de 9 de diciembre de 1931 quiso romper netamente con la tradición confesional española y orientar su planteamiento de la política religiosa sobre la base de la separación entre la Iglesia y el Estado. A este propósito parece responder su art. 3, que estableció con ejemplar laconismo: "El Estado español no tiene religión oficial"" (P. Lombardia, op. cit., pág. 116). 
con las libertades individuales y colectivas o, lo que es lo mismo, con el ejercicio de la libertad religiosa y de culto por parte de los individuos y de los grupos sociales. El párrafo tercero se destina a fijarle al poder público la obligación de establecer determinadas condiciones concretas de carácter social a efectos de que el ejercicio de aquellas libertades resulte efectivo y real. El texto es el siguiente:

"Artículo 2.9 1. La libertad religiosa y de culto garantizada por la Constitución comprende, con la consiguiente inmunidad de coacción, el derecho de toda persona a:

a) Profesar las creencias religiosas que libremente elija o no profesar ninguna; cambiar de confesión o abandonar la que tenía; manifestar libremente sus propias creencias religiosas o la ausencia de las mismas, o abstenerse de declarar sobre ellas.

b) Practicar los actos de culto y recibir asistencia religiosa de su propia confesión; conmemorar sus festividades; celebrar sus ritos matrimoniales; recibir sepultura digna, sin discriminación por motivos religiosos, y no ser obligado a practicar actos de culto o a recibir asistencia religiosa contraria a sus convicciones personales.

c) Recibir e impartir enseñanza e información religiosa de toda índole, ya sea oralmente, por escrito o por cualquier otro procedimiento $y$ elegir para sí, y para los menores no emancipados e incapacitados, bajo su dependencia, dentro y fuera del ámbito escolar, la educación religiosa y moral que esté de acuerdo con sus propias convicciones.

d) Reunirse o manifestarse públicamente con fines religiosos $y$ asociarse para desarrollar comunitariamente sus actividades religiosas de conformidad con el ordenamiento jurídico general y lo establecido en la presente Ley Orgánica.

2. Asimismo comprende el derecho de las Iglesias, Confesiones y Comunidades religiosas a establecer lugares de culto o de reunión con fines religiosos, a designar y formar a sus ministros, a divulgar y propagar su propio credo, y a mantener relaciones con sus propias organizaciones o con otras confesiones religiosas, sea en territorio nacional o en el extranjero.

3. Para la aplicación real y efectiva de estos derechos, los poderes públicos adoptarán las medidas necesarias para facilitar la asistencia religiosa en los establecimientos públicos militares, hospitalarios, asistenciales, penitenciarios y otros bajo su dependencia, así como la formación religiosa en centros docentes públicos.»

He clasificado en otra ocasión este contenido del artículo 2 de la LOLR de la forma que sigue: 
“l. Los derechos individuales

1. Libertad religiosa personal

2. Libertad de culto y asistencia religiosa

A) Positiva

a) Recibir asistencia religiosa de la propia confesión

b) Conmemorar las festividades

c) Celebrar los ritos matrimoniales

d) Recibir sepultura digna sin discriminación por motivos religiosos

B) Negativa

No ser obligado a practicar actos de culto o a recibir asistencia religiosa contraria a las propias convicciones personales

3. Información y enseñanza religiosa

4. Derechos de reunión, manifestación y asociación

II. Derechos colectivos

1. Origen y contenido

2. Sujetos." 120

Esta clasificación, que trata de presentar en una visión sistemática de conjunto el contenido real de la Ley, puede valorarse mejor si señalamos la clasificación que a su vez ha hecho el Profesor SOUTO de las libertades que es necesario garantizar para que quepa afirmar que el ordenamiento tutela con la suficiente efectividad el derecho fundamental de libertad religiosa. Téngase en cuenta que, a tenor del artículo 53.1 de la Constitución, "los derechos y libertades reconocidos en el Capítulo segundo del presente Título vinculan a todos los poderes públicos. Sólo por ley, que en todo caso deberá respetar su contenido esencial, podrá regularse el ejercicio de tales derechos y libertades, que se tutelarán de acuerdo con lo previsto en el artículo 161.1.a)".

M. J. CiÁurRIZ, op. cit., pág. 10. 
La LOLR, pues, al desarrollar el contenido del derecho de libertad religiosa, ha de respetar su contenido esencial, que Souto especifica como sigue:

«El derecho fundamental de libertad religiosa deberá garantizar, por tanto, las siguientes manifestaciones:

a) La libertad de profesar o no profesar, es decir, de tener o no tener las creencias religiosas elegidas libremente.

b) La libertad de declarar o no declarar las propias convicciones religiosas.

c) La libertad de culto, es decir, de realizar las prácticas religiosas propias de la confesión elegida.

d) La libertad ética o moral, es decir, la libertad de actuar conforme a las propias convicciones religiosas.

e) La libertad de información, es decir, de informar y ser informado sobre las creencias religiosas que se profesan.

f) La libertad de educación religiosa, y, por tanto, de recibir e impartir la enseñanza de las creencias asumidas.

g) La libertad de reunión, de manifestación y de asociación para realizar actividades religiosas." ${ }^{121}$

Como el propio artículo 2 de la LOLR expresa, esta serie de manifestaciones del derecho fundamental de libertad religiosa corresponde tanto a los individuos como a los grupos confesionales, es decir, ha de encontrar su concreción tanto en las libertades individuales como colectivas. $Y$ aunque es fácil distinguir en el plano de las clasificaciones técnicas las manifestaciones individuales de la libertad de las colectivas, la realidad es que unas y otras se mezclan entre sí y hacen compleja la distinción en muchos casos. De un lado, en efecto, las asociaciones no son sino sumas de individuos, nacidas del ejercicio del derecho individual de asociación ${ }^{122}$, y a quienes la concurrencia de varias voluntades asociati-

121 J. A. Souto, op. cit., pág. 87. Los subrayados son del autor.

122 Una de las libertades «que el ordenamiento español intenta proteger es la de asociación, concebida como la garantía de que, dentro de los límites fijados por el ordenamiento, el individuo pueda constituir grupos, pueda agruparse $y$ actuar a su través en la vida social y, consecuentemente, en el tráfico jurídico. Así pues, la existencia de asociaciones (empleo la categoría sin especiales pretensiones de precisión técnica), la existencia de las mismas en el mundo del Derecho, es, en 
vas $^{123}$ dota de entidad $y$ el ordenamiento de personalidad si es el caso ${ }^{124}$; $y$ los fines colectivos se resuelven en el ejercicio de muchos derechos personales simultáneamente ${ }^{125}$. Las actividades colectivas están, por supuesto, al servicio del bien de las personas ${ }^{126}$. Y si no hay duda de que los actos administrativos, de funcionamiento, etc., son actividades del grupo - de la confesión o comunidad- que en todo caso tienden al bien de las personas ${ }^{127}$, múltiples actos asistenciales y de culto resultan ser un conjunto de acciones individuales coordinadas. Los propios documentos - los acuerdos - por su parte mezclan en su articulado derechos personales y colectivos en una necesaria amalgama, de forma que la distinción es más técnica y formal que existencial. Y así lo tendremos en cuenta en el resto del presente estudio.

\section{c) La libertad religiosa personal}

Refiriéndonos ahora de forma determinada al contenido de estas libertades o, lo que es lo mismo, y dentro del sentido de lo expuesto, al

primer término, una consecuencia de la vocación del ordenamiento de proteger los derechos individuales $y$, consecuentemente, de proteger el específico derecho de asociación" (I. C. IBÁN, "Las confesiones religiosas", en el volumen de I. C. IBÁN, L. Prieto Sanchis y A. Motilla, cit., pág. 217).

${ }^{123}$ En la concurrencia de voluntades individuales que se asocian se opera esa exigencia de la doctrina que ve a los grupos como expresión de la participación en el poder de los miembros reales de la sociedad, lo que P. J. VILADRICH (op. cit., pág. 247) ha llamado "la valoración democrática de los grupos sociales reales".

${ }_{124}$ El medio previsto al respecto en nuestro ordenamiento suele ser el del registro: "De la inscripción se deriva un efecto de especial importancia en el orden jurídico: la atribución de personalidad jurídica a la confesión o comunidad religiosa. A su vez, la adquisición de personalidad jurídica garantiza la autonomía de la confesión para establecer sus propias normas de organización" (J. A. Souto, op. cit., pág. 92).

125 "Probablemente se trate de una afirmación con un soporte moral o ético y no estrictamente jurídico, pero tengo para mí que el punto de referencia de todo ordenamiento jurídico debe ser el individuo" (I. C. IBÁN, "Las confesiones religiosas", en la obra de I. C. Ibán, L. Prieto Sanchis y A. Motilla, cit., pág. 217).

${ }_{126}$ Ese sentido puede darse a la expresión "No concentremos la atención sobre el derecho, sino sobre los hombres" (R. WIETHOLTER, Las fórmulas mágicas de la ciencia jurídica, Madrid, 1991), con la que se quiere salir al paso del protagonismo de la colectividad organizada y de sus normas de funcionamiento frente a la irrenunciable primacía de la persona.

127 "La Ley Orgánica de Libertad Religiosa reconoce, como acabamos de ver, el derecho de los individuos a asociarse con fines religiosos. Pues bien, a ese grupo o estructura resultante del ejercicio del derecho de asociación, la legislación le atribuye subjetividad jurídica y le reconoce, en cuanto tal, determinados derechos" (J. A. Souto, op. cit., pág. 92). 
ejercicio de la libertad religiosa por los individuos y las confesiones ${ }^{128}$, empezaremos por la que constituye la base de toda la estructura del ejercicio de la libertad, y que ha quedado clasificada como la libertad religiosa personal. Ésta "comprende aquellas actitudes que el individuo puede adoptar ante el hecho religioso y que consisten en el derecho a elegir y profesar sus creencias religiosas y, por supuesto, también el derecho a elegir no tener ninguna creencia religiosa. Como es lógico, la elección de creencias o la decisión de no tener creencias, garantizada legalmente, implica el derecho a pertenecer a una determinada confesión religiosa. Este derecho abarca, por supuesto, la libertad de abrazar una confesión y la libertad de abandonarla, ya sea para abrazar una nueva y, por tanto, cambiar de religión 0 , simplemente, renunciar a pertenecer a ninguna religión. Este derecho de pertenencia a una confesión religiosa (de profesión, según el término utilizado por la Ley) está reconocido en los textos internacionales, si bien es oportuno recordar la anécdota ocurrida con los países árabes que, en la discusión del artículo 18 de la Declaración Universal de los Derechos Humanos, se opusieron al reconocimiento del derecho a cambiar de religión. Una actitud respetuosa con estas pretensiones se refleja en la redacción del artículo 18 del Pacto Internacional de Derechos Civiles y Políticos, en el que se sustituyó la redacción originaria: "cambiar de religión o creencias", por la de "adoptar la religión o creencias de su elección". La libertad de profesión de unas creencias religiosas lleva aparejado el derecho a declarar y manifestar esas creencias. Manifestación, en todo caso, libre y voluntaria, porque se garantiza la libertad de abstenerse de declarar y se prohíbe cualquier coacción tendente a que se produzca dicha manifestación" ${ }^{129}$.

Esta libertad personal, individual, de adopción y profesión de las creencias religiosas que cada persona desee, ha de ser considerada una manifestación del derecho de libertad religiosa que posee un carácter propedéutico con relación a todo el resto de los derechos en que dicha libertad religiosa se manifiesta y que la Ley reconoce. Es, en efecto, presupuesto previo al resto de los derechos - culto, enseñanza, asistencia religiosa, etc.-, el derecho de elegir una creencia, cambiar de religión, o no practicar ni aceptar ninguna.

${ }^{128}$ Del derecho de libertad «los individuos son titulares originarios; los grupos lo son derivados. Si se reconoce a esos grupos esa titularidad, la razón no es otra que para hacer reales y efectivas la igualdad y la libertad del individuon (D. LLAMAZARES, op. cit., pág. 653).

129 J. A. Souto, op. cit., págs. 88-89. 


\section{LA LIBERTAD RELIGIOSA EN LOS ACUERDOS CON LAS CONFESIONES}

\section{a) Los sujetos titulares de la libertad religiosa}

En este sentido, debemos observar que el derecho de libertad religiosa aparece como presupuesto tanto de los Acuerdos celebrados en 1979 entre la Iglesia Católica y el Estado como de los tres posteriores Acuerdos con confesiones no católicas. Nótese que todos ellos aparecen redactados en el sentido de tutela de los derechos comunitarios antes que de los derechos individuales ${ }^{130}$. $\mathrm{O}$, dicho de otro modo, toman como sujetos inmediatos de la relación jurídica con el Estado a las confesiones y no a los individuos ${ }^{131}$. El artículo 1.-1, en efecto, del Acuerdo Jurídico con la Santa Sede expresa que uel Estado español reconoce a la Iglesia Católica el derecho de ejercer su misión apostólica y le garantiza el libre ejercicio de las actividades que le son propias y, en especial, las de culto, jurisdicción y magisterion.

Por su parte, los Acuerdos con las Comunidades Evangélica, Israelita e Islámica, cuya redacción y construcción sistemática ofrece un notorio paralelismo entre los tres, determinan igualmente en sus correspondientes artículos iniciales el sujeto corporativo de la relación jurídica con el Estado que cada Acuerdo regula. Así, el artículo 1.1 del Acuerdo con los Israelitas: "Los derechos y obligaciones que se deriven de la Ley por la que se apruebe el presente Acuerdo serán de aplicación a las Comunidades Israelitas que, figurando inscritas en el Registro de Entidades Religiosas, formen parte o posteriormente se incorporen a la Federación

130 "Son titulares de los derechos de igualdad y de libertad ideológica y religiosa tanto los individuos como las comunidades para utilizar la expresión del artículo 16 de la Constitución. Cierto que el artículo 14 parece referirse únicamente a los individuos como sujetos del derecho de igualdad, a diferencia del artículo 16 que refiere el de libertad religiosa e ideológica tanto a individuos como a comunidades; pero es preciso tener en cuenta que ese silencio del artículo 14 queda subsanado por el artículo 9.2, que tipifica como titulares de la igualdad y de la libertad tanto al individuo, cuanto a los grupos en que se integran (D. LLAMAZARES, op. cit., pág. 653).

${ }_{131}$ "Determinadas tendencias doctrinales, que aquí no cabe analizar, pero que han incidido en la configuración del actual sistema español, han llevado también a la consideración de las asociaciones como titulares de derechos, incluso de derechos fundamentales. De tal manera que el reconocimiento de las asociaciones vendría justificado en razón de la existencia de un derecho subjetivo individual de asociación, pero que, a su vez, genera nuevos titulares de derechos subjetivos, siendo tales titulares las propias asociaciones" (I. C. IBán, op. cit., pág. 219). 
de Comunidades Israelitas de España, mientras su pertenencia a la misma figure inscrita en el mencionado Registro". Idéntico es el texto del Acuerdo con los musulmanes, artículo 1.1: "Los derechos y obligaciones que se deriven de la Ley por la que se apruebe el presente Acuerdo, serán de aplicación a las Comunidades Islámicas inscritas en el Registro de Entidades Religiosas, que formen parte o posteriormente se incorporen a la "Comisión Islámica de España" o a alguna de las Federaciones Islámicas inscritas integradas en dicha Comisión mientras su pertenencia a las mismas figure inscrita en dicho Registro". Y prácticamente literal es también el texto del equivalente artículo 1.1 del Acuerdo con los Evangélicos: "Los derechos y obligaciones que se deriven de la Ley por la que se apruebe el presente Acuerdo serán de aplicación a las Iglesias que, figurando inscritas en el Registro de Entidades Religiosas, formen parte o se incorporen posteriormente a la Federación de Entidades Religiosas Evangélicas de España, mientras su pertenencia a la misma figure inscrita en el mencionado Registro".

La estrecha similitud de las tres redacciones indica una clara voluntad por parte del Estado de dar un tratamiento lo más igual posible a todas las Comunidades o Confesiones que entren dentro del campo de aplicación de la Ley ${ }^{132}$, voluntad que encuentra asimismo un reflejo en el resto de los tres sucesivos articulados. Aplicación estricta del principio de igualdad del artículo 1 de la Constitución, que en el propio desarrollo del articulado habrá de acomodarse - a su vez en aplicación del principio de justicia- a las peculiaridades propias de cada Confesión. La doctrina, en efecto, no ha dejado de observar que "los asuntos, objeto de cada Acuerdo, son comunes a todos ellos, aunque adaptados a las peculiaridades de cada religión" ${ }^{133}$.

Pero, en todo caso, hemos de señalar que la libertad religiosa individual, la libertad del ciudadano para ejercer la opción que prefiera en el campo de las creencias, actúa como un prius a la existencia misma de las Comunidades, que existen en la medida en que la correspondiente elección de una fe y de la pertenencia a una confesión es decidida libremente por un número determinado de individuos ${ }^{134}$; dato que si supone la posibilidad misma de constitución de una Federación o Comunidad re-

132 D. LlamazARES se ha ocupado de tipificar a las confesiones religiosas a través de las notas que deben considerarse esenciales para que un grupo pueda merecer aquella calificación y entrar dentro del supuesto de hecho del artículo 16 de la Constitución. Vid. al respecto su op. cit., págs. 654-655.

${ }_{133}$ J. A. Souto, op. cit., pág. 543.

${ }^{134}$ La elección de una fe, un credo, es uno de los elementos integrantes junto con la organización ministerial y el culto- que caracterizan a un grupo religioso (Vid. D. Llamazares, op. cit., pág. 654). 
ligiosa en España, cobra particular relieve si se recuerda que la LOLR requiere en su artículo 7.1 el "notorio arraigo en España" de las Comunidades religiosas con las que haya de llegarse a Acuerdos o Convenios de Cooperación ${ }^{135}$. Exigencia lógica en cuanto que constituye una forma de dar realidad técnica al deber que en abstracto fijan al Estado tanto la Constitución como la propia LOLR ${ }^{136}$ : el deber de tener "en cuenta las creencias religiosas existentes en la sociedad española» ${ }^{137}$.

El posterior desarrollo, en el articulado de todos los Acuerdos, de los derechos reconocidos a las Comunidades o Confesiones, supondrá la atribución, el reconocimiento o la tutela de variados derechos individuales, $y$ de ello haremos mención a medida que hagamos particular referencia a los mismos.

\section{b) Libertad de culto $y$ asistencia religiosa}

Objeto ineludible de tutela por parte de la Ley había de ser la libertad de culto, toda vez que el propio artículo 1 -como arriba quedó analizado- se refiere al culto juntamente con la libertad religiosa. La escueta referencia al mismo se contiene, como vimos al recoger el texto del artículo 2 de la propia LOLR, en la letra b) de su apartado 1: «Practicar los actos de culto y recibir asistencia religiosa de su propia confesión". La unión de dos derechos que, por relacionados que se encuentren, no pueden confundirse - los actos de culto y la asistencia religiosa- ${ }^{138}$, ha mo-

135 Vid., sobre el "notorio arraigo" y su exigencia constitucional, M. J. VILLA RoBledo, "Reflexiones en torno al concepto de "notorio arraigo" en el art. 7 de la Ley Orgánica de Libertad religiosa", en Anuario de Derecho Eclesiástico del Estado, I, 1965, págs. 143-183.

${ }_{136}$ "Cada una de las confesiones que han suscrito estos Acuerdos han merecido la calificación de confesiones que, además de estar inscritas, gozan de notorio arraigo en la sociedad española, según el Informe de la Comisión Asesora de Libertad Religiosa, que el 14 de diciembre de 1984 emitió informe favorable sobre las Iglesias Evangélicas de España y las Comunidades Israelitas, mientras que el 14 de julio de 1989 emitía informe favorable respecto a las Comunidades Islámicas" (J. A. Souto, op. cit., pág. 542).

${ }_{137}$ Artículo 7.1 de la LOLR en dependencia del artículo 16.3 de la Constitución.

${ }^{138}$ No es extraño encontrar en la doctrina inevitables vinculaciones entre culto y asistencia religiosa; p. ej., J. M. GonZÁLEZ DEL. VALLE aludirá, al referirse a la asistencia, a los lugares destinados al culto, atendidos por ministros de culto, que a su vez requieren centros para su formación (Derecho Eclesiástico español, cit., pág. 162). El hecho es inevitable, dada la estrecha vinculación entre ambos conceptos, que no deben sin embargo confundirse. 
tivado tal vez que la doctrina tienda a subrayar el segundo con menor preocupación por el primero; se dan como manifestaciones de la asistencia religiosa las que el propio articulado seguidamente inserta: conmemoración de festividades, celebración de ritos matrimoniales, recepción de sepultura.

Es de notar que en tales actividades están presentes a la vez el culto y la asistencia religiosa: la celebración de festividades suele suponer en todas las confesiones la realización de determinados actos cultuales, en los cuales los creyentes reciben sin duda un servicio o asistencia religiosa por parte de los ministros del culto; en los ritos matrimoniales religiosos está igualmente siempre presente el culto, al par que la recepción de asistencia; y asimismo la asistencia que supone dar sepultura a los cadáveres va en todas las confesiones acompañada de ritos de carácter cultual.

Al propósito, se ha señalado que la garantía de estos derechos por parte de la LOLR es una "garantía negativa, dado que no se obstaculiza, ni impide la práctica o la recepción de dicha asistencia. Ciertamente, no se garantiza la prestación de las mismas, porque los poderes públicos no pueden intervenir como garantes de la prestación de estos servicios. Estamos, pues, en presencia de un derecho-libertad, que garantiza el ámbito de autonomía privada para la realización de una serie de actividades religiosas. No es, por tanto, un derecho-prestación que pueda exigirse a los poderes públicos, que facilite los medios necesarios para la adecuada prestación de los mismos» ${ }^{139}$.

Esto seria exacto si solamente se estuviese hablando de la asistencia religiosa, y aun habrian de hacerse las observaciones que seguirán. Pero diverso es el caso en relación con la libertad de culto, pues la práctica del culto no puede reducirse a la esfera de la vida privada, y el culto público no solamente requerirá del Estado una garantía negativa, sino que será frecuente que deba realizar actos de garantía positiva: piénsese por ejemplo en las procesiones, celebraciones litúrgicas al aire libre, y situaciones similares, que requerirán alteraciones del tráfico, disponibilidad de espacios públicos, etc. No es infrecuente que la celebración de festividades religiosas requiera algunas de esas manifestaciones cultuales en las que la garantía de los poderes públicos no podrá limitarse a la permisión o garantía-negativa.

$Y$ ello sin contar con que también la garantía estatal de la libertad de culto y de asistencia religiosa habrá de adoptar formas positivas cuan- 
do deba facilitar tales asistencia y culto, que sin una actitud y aun una actividad positiva del poder público no podrían llevarse a la práctica: actos litúrgicos y asistenciales en centros estatales del tipo de los cuarteles, hospitales, establecimientos penitenciarios y similares ${ }^{140}$.

Obligación que aparece incluso reconocida en la propia LOLR, cuyo artículo 2.3 recordamos que establecía que upara la aplicación real y efectiva de estos derechos, los poderes públicos adoptarán las medidas necesarias para facilitar la asistencia religiosa en los establecimientos públicos militares, hospitalarios, asistenciales, penitenciarios y otros bajo su dependencia, así como la formación religiosa en centros docentes públicos». Tema este último del que trataremos más adelante.

Como también recuerda la doctrina, "si bien el desarrollo legal y con carácter general de la libertad religiosa no comprende este carácter de prestación, sin embargo, a través de estipulaciones concretas (Acuerdos) con las confesiones religiosas los poderes públicos pueden asumir la obligación de facilitar dicha prestación" " ${ }^{141}$. Ya hemos indicado que sí cabe la hipótesis de que el Estado esté obligado a una prestación positiva en orden al culto y la asistencia religiosa; de todos modos, el lugar más adecuado para fijar y desarrollar tal deber son efectivamente los Acuerdos, como de hecho ha sucedido en este caso.

\section{c) El contenido de los Acuerdos}

Ya se ha hecho referencia de pasada al estricto paralelismo con el que están redactados los tres Acuerdos hasta hoy firmados por el Estado dentro del marco de la LOLR. "Los asuntos, objeto de cada Acuerdo, son comunes a todos ellos, aunque adaptados a las peculiaridades de cada religión. Se regulan, así, el Estatuto de los ministros de culto; la protección jurídica de los lugares de culto; efectos civiles del matrimonio religioso; asistencia religiosa en establecimientos públicos; enseñanza religiosa en centros docentes y beneficios fiscales. Por último, los Acuerdos con la Comisión Islámica y con la Federación de Comunidades Israelitas presentan dos novedades respecto al otro Acuerdo: la protección del pa-

140 "La doctrina tiende, a mi modo de ver indebidamente, a centrar el tema de la asistencia religiosa en torno a las situaciones de sujeción especial, en las que el individuo ve disminuida su libertad, como en los casos de internamiento penitenciario u hospitalario, etc." (J. M. González del VALLE, op. cit., pág. 161).

141 J. A. Souto, op. cit., pág. 89. 
trimonio histórico-artístico religioso y la protección de ciertas marcas de productos alimentarios y cosméticos, elaborados de acuerdo con la Ley judia o la Ley islámica, respectivamente» ${ }^{142}$.

LLAMAZARES ofrece asimismo una interesante clasificación del contenido de los Acuerdos que estructura de la siguiente forma:

«a) Cooperación directa con las Iglesias o Comunidades e indirecta con los ciudadanos

1) Reconocimiento de la personalidad jurídica

2) Autonomía

3) Régimen fiscal

4) Cooperación en materia de patrimonio histórico, artístico y cultural

5) Productos alimenticios y cosméticos judios ${ }^{143}$

b) El Estado como mero intermediario entre Confesiones y ciudadanos miembros de las mismas

a) Contribución estatal al sostenimiento económico de las Confesiones

b) Enseñanza y asistencia religiosa en centros públicos

c) Cooperación directa con los ciudadanos e indirecta con las confesiones

1) Descanso semanal

2) Matrimonio en forma religiosa

3) Sacrificio ritual judio de animales." ${ }^{144}$

142 J. A. Souto, op. cit., pág. 543.

143 El texto de Llamazares que citamos es anterior a la firma del Acuerdo con la Federación musulmana.

144 D. Llamazares, Acuerdos del Estado con las confesiones religiosas (FEREDE y FCl), Madrid, s.f., págs. 7-8. 


\section{d) Los ministros del culto}

En relación con el estatuto de los ministros del culto, el artículo 3 del Acuerdo con la Federación Israelita establece, en efecto, quienes tienen la consideración de ministros de culto de la misma, y garantiza su actividad y en concreto su derecho a no declarar sobre hechos «que les hayan sido revelados en el ejercicio de funciones de culto o de asistencia religiosa"; la obligación del servicio militar, que tales ministros conservan, pueden desempeñarla en funciones asistenciales religiosas, y sus estudios de formación como rabinos dan derecho a la misma prórroga militar que los estudios públicos que se realizan por los ciudadanos españoles (artículo 4); tendrán derecho a la seguridad social para sí y sus familias como trabajadores por cuenta ajena en iguales condiciones a las establecidas por la legislación para los clérigos católicos (artículo 5).

Los militares $-y$ demás personas que presten servicios en las Fuerzas armadas- y que sean de religión judía tendrán derecho a recibir asistencia religiosa y a participar en los ritos y actos propios de su culto (artículo 8); y la misma asistencia religiosa se garantiza a quienes estén internados en centros penitenciarios y hospitalarios o similares del sector público (artículo 9). Es decir, el culto y la asistencia, contenidos en la LOLR como un derecho a garantizar por el Estado, recibe precisamente en los Acuerdos su correspondiente desarrollo y determinación, ya que en los otros dos Acuerdos, el evangélico y el islámico, las mismas prescripciones se establecen con similares palabras y en los mismos artículos.

\section{e) Los lugares sagrados}

Aunque líneas atrás hemos aludido a la posibilidad de un culto público en lugares exteriores, $o$ al menos no pertenecientes a la Comunidad religiosa de que se trate, y acerca de los cuales es posible que se requiera una asistencia positiva del poder público para garantizar o tutelar las actividades cultuales, lo normal será el desarrollo del culto en edificios ad hoc, propiedad de las Comunidades y sobre los que la tutela del Estado se hará a través del respeto a los mismos y a las actividades en ellos llevadas a cabo, una vez que se determina qué lugares poseen la necesaria condición de edificios sagrados destinados a finalidades religiosas. 
Resulta igualmente paralelo el tratamiento dado a los lugares de culto por parte de los tres Acuerdos. En relación con la tutela por parte de la norma de los derechos individuales, de que venimos ocupándonos, y de los colectivos, los lugares de culto poseen un carácter instrumental, al servicio de la Comunidad tanto como de sus miembros. Dependerá de las formas de culto y vida religiosa propias de cada confesión el que las actividades a realizar en el interior de los templos y lugares sagrados posean un carácter exclusivamente colectivo, o también individual; y aún cabe distinguir a este respecto, p. ej., entre iglesias, sinagogas y mezquitas, por un lado, y cementerios por otro. Pero, en todo caso, toca a la norma garantizar a los lugares de culto dispensándoles una situación jurídica propia, a cuyo fin atienden los respectivos artículos 2 de los tres textos legales.

Así pues, el artículo 2 del Acuerdo con la Federación israelita dispone que "a todos los efectos legales", son lugares de culto los pertenecientes a las correspondientes Comunidades integradas en aquélla, $y$ que se encuentren de forma permanente y exclusiva destinados a las funciones de culto, formación o asistencia religiosa. Una oportuna certificación al respecto de la correspondiente Comunidad hará fe de tal condición, y tales lugares gozarán en consecuencia de la inviolabilidad establecida por las leyes; no podrán por otra parte ser expropiados sin oír previamente a la Federación Israelita, ya que la expropiación supone la desafección de las funciones a que se encuentran destinados y de la protección consiguiente que les otorga el ordenamiento.

Del mismo modo, deberán ser privados de su carácter sagrado previamente a su demolición, salvo los casos previstos normativamente para situaciones de urgencia o peligro. $Y$ un tratamiento similar gozan los cementerios judíos; los israelitas podrán poseer tanto cementerios privados como parcelas propias en los cementerios municipales, en los que podrán seguirse los ritos funerarios propios, y trasladar a ellos a los difuntos tanto actualmente inhumados en otros lugares como fallecidos en adelante en localidades en los que no exista un cementerio judío. El Acuerdo islámico reitera tales normas en su artículo 2 con muy pocas variantes: se menciona en él que los lugares sagrados están exentos de servidumbres a tenor de la ley de Expropiación Forzosa; y se añade que el Estado protegerá la inviolabilidad de los archivos y documentos de la $\mathrm{Fe}$ deración y de las Comunidades islámicas. Nada se menciona, en cambio, sobre cementerios en el Acuerdo con la Federación evangélica, y la doctrina ha pasado en general sobre este dato sin parar en él su atención. 


\section{f) Las funciones sagradas}

Dos materias, estrechamente relacionadas entre si y relativas al culto y formas de vida de los miembros de las confesiones, motivan redacciones distintas, en los tres Acuerdos, de los artículos que a las mismas se refieren, habida cuenta de las importantes diferencias que distinguen a cada una de las confesiones en esos campos. Se trata de las festividades religiosas y de las funciones sagradas, temas que afectan tanto a las Comunidades en cuanto tales como a sus miembros.

Los respectivos artículos 6 de los tres Acuerdos fijan el concepto legal de función religiosa, en este caso con redacciones propias, en cuanto que han de acomodarse a las peculiaridades propias de cada una de las tres Confesiones. Los Acuerdos israelita e islámico recurren al sistema de remitirse en dichos artículos, para definir las funciones religiosas propias, a la ley y tradición religiosas respectivas; el Acuerdo con los evangélicos, en cambio, realiza una descripción más detallada de tales funciones, que son las dirigidas directamente al ejercicio del culto, administración de Sacramentos, cura de almas, predicación del Evangelio y magisterio religioso.

Tal artículo es una de las más claras huellas, en los Acuerdos, del carácter cristiano de las confesiones evangélicas y por tanto de su vecindad a la Iglesia católica en lo que hace a medios de santificación y funciones religiosas, mientras que las tradiciones judías e islámicas al respecto poseen caminos propios distantes de las formas católicas del culto, formas que por siglos han sido, y siguen siendo, absolutamente mayoritarias en España. Las referencias a los sacramentos, el Evangelio, la cura de almas, son habituales en el lenguaje religioso del cristianismo, tanto protestante como católico, y su presencia en el artículo 6 del Acuerdo con la Federación evangélica no introduce ningún elemento nuevo o desconocido en la tradición religiosa de España. Otro es evidentemente el caso de los Acuerdos con musulmanes y judíos; el artículo 6 del Acuerdo con aquéllos expresa que "a los efectos legales, son funciones islámicas de culto, formación y asistencia religiosa, las que lo sean de acuerdo con la Ley y la tradición islámica, emanadas del Corán o de la Sunna y protegidas por la Ley Orgánica de Libertad Religiosa". Y el mismo artículo del Acuerdo con los israelitas establece a su vez que "a todos los efectos legales, se consideran funciones propias de la religión judía las que lo sean con arreglo a la Ley y a la tradición judia, entre otras las de religión que se derivan de la función rabínica, del ejercicio del culto, de la prestación de servicios rituales, de la formación de los rabinos, de la enseñanza de la religión judía y de la la asistencia religiosa". 
No puede menos de observarse, en los textos de los tres artículos 6 de los respectivos Acuerdos, una curiosa graduación de los datos en ellos recogidos, según la mayor o menor proximidad del concepto de función religiosa y de sus fuentes normativas al Catolicismo. En efecto, como ya se ha señalado, el Acuerdo evangélico trata el tema de modo similar a como podría tratarlo un Acuerdo con la Iglesia católica; el Acuerdo con los israelitas se aparta en cuanto que no puede hacer mención de formas cristianas de culto o asistencia (sacramentos, cura de almas), pero tampoco cita las fuentes religiosas que regulan en el judaísmo la materia, ya que el Viejo Testamento es también fuente para el cristianismo, en cuyo ambiente se puede sobreentender cuáles sean "la Ley y la tradición judía" en tanto que el propio cristianismo participa de ellas. Para el caso islámico, la Ley coránica y su Libro y tradiciones son ajenos al Cristianismo, y precisan y obtienen una mención específica. Los Acuerdos reflejan así con mayor propiedad la adecuación de la igualdad a la libertad, que se garantiza mejor creando para cada confesión la normativa que precisa y en la forma en la cual la precisa.

\section{g) Las festividades religiosas y los problemas que generan}

En estrecha relación con el tema de las funciones religiosas está el de las festividades del mismo carácter. El principal problema que genera en el ámbito del Derecho eclesiástico es el relacionado con el descanso laboral. Las festividades religiosas, como algo propio de cada religión o confesión religiosa, comportan obligaciones litúrgicas que no salen fuera del ámbito interno de la comunidad, pero al mismo tiempo dan lugar frecuentemente a actividades externas que exigen una actitud y aun una actividad positiva del poder político; entre éstas sobresale la exigencia de descanso laboral que las diferentes confesiones pueden pretender situar en dias distintos de la semana - descanso semanal-o en fechas propias y especiales del año - festividades-.

Por lo que hace al descanso semanal, existe en todo el Occidente cristiano una tradición plurisecular que lo liga al domingo, tradición que de hecho ha determinado la casi universalidad de la aceptación de esa jornada como festiva a efectos laborales. En el derecho español, exactamente en el Estatuto de los Trabajadores, artículo 37.1, el descanso semanal mínimo queda fijado para el domingo entero y medio día más, sea la tarde del sábado o la mañana del lunes; se acepta en el mismo texto que «por disposición legal, convenio colectivo, contrato de trabajo o permiso expreso de la autoridad se regule otro régimen de descanso laboral para actividades concretas". 
Dado que tanto los judíos como los musulmanes, $y$ algunas confesiones evangélicas, no consideran día festivo el domingo sino otro de la semana, los Acuerdos han tenido que prever excepciones al principio general del Estatuto citado que fija para los trabajadores españoles el descanso laboral de acuerdo con la ya referida tradición cristiana generalizada en el Occidente.

Para los israelitas, el artículo 12 del correspondiente Acuerdo prevé que su descanso laboral tenga lugar durante el sábado más la tarde del viernes, "siempre que medie acuerdo entre las partes", es decir, entre la Federación de Comunidades Israelitas de España o su miembros y la entidad en que el empleado de esta confesión trabaja. Estas fechas sustituyen en su caso a las marcadas por el artículo 37.1 del Estatuto de los trabajadores.

Siendo diversos los modos propios de cada confesión de entender y celebrar el descanso semanal, existen diferencias entre el citado artículo 12 y el también 12 del Acuerdo con los musulmanes. A tenor de éste, los miembros de las Comunidades Islámicas que lo deseen «podrán solicitar la interrupción de su trabajo los viernes de cada semana, día de rezo colectivo obligatorio y solemne de los musulmanes, desde las trece treinta horas hasta las dieciséis treinta horas, así como la conclusión de la jornada laboral una hora antes de la puesta del sol, durante el mes de ayuno (Ramadán)". El artículo añade que uen ambos casos, será necesario el previo acuerdo entre las partes" y que "las horas dejadas de trabajar, deberán ser recuperadas sin compensación algunan.

Sistema sin duda muy diferente del establecido con los israelitas, y que de hecho no comprende propiamente hablando una jornada de descanso completa; por lo que ha de entenderse que mientras los judíos tienen su día y medio de descanso en viernes y sábado en lugar del descanso normal del domingo y otro medio día, y que por tanto el régimen económico de este descanso es idéntico al que tienen los trabajadores españoles que se someten al Estatuto de los Trabajadores en este punto, los musulmanes tienen como día de descanso el mismo que la generalidad de los españoles, y en régimen económico igual; si además quieren tener unas horas libres de vez en cuando, han de pedirlo personal y precisamente y las obtienen en su caso con la obligación de recuperarlas sin compensación económica. $Y$ es que ya poseen el derecho normal de cualquier trabajador al descanso de día y medio, y sus horas de oración especiales constituyen una benevolencia del poder público de la que solamente pueden beneficiarse a efectos religiosos, no económicos.

Las confesiones evangélicas, por lo general, mantienen como día de descanso semanal el domingo, al igual que los católicos, una vez más 
por su común raíz cristiana. Vale, pues, para ellas el régimen general del Estatuto de los Trabajadores. Sin embargo, existen excepciones, pues la Unión de Iglesias Adventistas del Séptimo Día, y otras de menor entidad, integradas en la FEREDE, tienen como dia de precepto el sábado. Para ellas establece el artículo 12 del correspondiente Acuerdo que el descanso semanal laboral upodrá comprender, siempre que medie acuerdo entre las partes, la tarde del viernes y el día completo del sábado, en sustitución del que establece el artículo 37.1 del Estatuto de los Trabajadores como regla general». La solución, pues, es idéntica a la acordada con los israelitas, lo cual es lógico en la medida en que estas confesiones han optado por atenerse a la tradición judía en lugar de a la cristiana; opción en todo caso legítima, como lo sería cualquiera otra, y lógica en la medida en que el judaísmo está en el origen del cristianismo en tantas instituciones y costumbres, y las confesiones cristianas, si por lo común aceptaron el domingo como Día del Señor, pudieron como en estos casos preferir conservar el modelo hebreo.

Los preceptos de los artículos 12 de los tres Acuerdos completan con otros detalles la normativa sobre el descanso semanal. En el caso de las Iglesias evangélicas, una particular atención se presta a aquéllos de sus miembros que cursen estudios o concurran a oposiciones de carácter profesional. Quienes perteneciendo a tales confesiones «cursen estudios en centros de enseñanza públicos y privados concertados, estarán dispensados de la asistencia a clase y de la celebración de exámenes desde la puesta del sol del viernes hasta la puesta del sol del sábado, a petición propia o de quienes ejerzan la patria potestad o tutelan, si así lo necesitaren.

Debe observarse el carácter imperativo de esta norma, que la distingue de la referente a los trabajadores; éstos solamente tendrán libre el sábado cuando medie acuerdo entre las partes, de modo que la empresa puede - hay que suponer que justificadamente, aunque la norma pactada citada no lo indica así- negarse a reconocerles el ejercicio de ese derecho; para los estudiantes, en cambio, el descanso del sábado concedido en el Acuerdo se impone como un deber a los centros educativos. La razón hay que buscarla, en buena lógica, en el diferente tipo de actividad de unos y otros; mientras para la empresa el abstencionismo laboral de una parte de sus trabajadores en un día en que todos los demás trabajan puede ser fuente de graves perjuicios, no lo es para un centro docente, cuanto más que se ha hecho normal y casi universal en España el no funcionamiento de éstos en los fines de semana. $Y$, por lo que hace a los opositores, dispone el artículo que citamos que sus exámenes y pruebas selectivas que hubiesen de celebrarse en el período de tiempo indicado como libre para los estudiantes se trasladen para una fecha alternativa, "cuando no haya causa motivada que lo impida". 
El que la norma relativa a los estudiantes solamente toque a los centros públicos y privados concertados - privados que se benefician de ayudas económicas públicas a cambio de someterse a una disciplina similar a los colegios públicos-, se debe a que los colegios privados no concertados son absolutamente libres para aceptar el alumnado que deseen y rechazar al que deseen, y para marcar las reglas internas de su funcionamiento.

La mención de esta causa es novedad en el articulado que referimos, y ya hemos observado que no se la menciona - como hubiese sido de desear - al hablar del acuerdo entre las partes para permitir la alteración de la jornada de descanso laboral, con lo que se deja en manos de la empresa el negarse a todo acuerdo razonable sin una real exigencia de motivo justificante. Tampoco aquí se indica a quién toca juzgar de la motivación de la causa por la que la administración pública podría negarse a permitir a los evangélicos a los que beneficia el artículo que celebren su oposición o prueba en otra jornada especialmente seleccionada para ellos, distinta del sábado. Tales lagunas pudieran con el tiempo dar lugar a problemas de difícil solución práctica.

El artículo 12 del Acuerdo con los musulmanes contiene normas similares, adecuadas al caso concreto de esta confesión. Dado que, como se verá, dicho artículo enumera también las festividades religiosas musulmanas a lo largo del año - lo que no sucede con el Acuerdo evangélico-, sus párrafos 3 y 4 dispensan de la asistencia a clase tanto en esas fiestas como en las horas del viernes destinadas a la oración, a las que ya se había referido el mismo artículo al tratar de los trabajadores. Una vez más el precepto es imperativo, en el mismo sentido y por los mismos motivos que hemos aducido al tratar de las confesiones evangélicas. $Y$ los opositores reciben también el mismo trato que los evangélicos, para sus días festivos y horas de oración tal y como los estudiantes, mediando en este supuesto asimismo la posibilidad de que una causa motivada a juicio de la Administración pública aconseje no actuar en algún caso el privilegio.

Idéntico totalmente es el tratamiento dado al tema en el Acuerdo con los israelitas, siendo en este caso los días a tomar en cuenta el sábado y sus propias festividades religiosas anuales. Estas festividades, que era preciso enumerar para los judíos y los musulmanes - una vez más por extraños a las tradiciones cristianas que en buena medida comparten católicos y evangélicos- están recogidas también en los artículos 12 de ambos Acuerdos. Son, en el caso israelita, el Año Nuevo (1.ํ y $2 .^{\circ}$ día), el Día de la Expiación, la Fiesta de las Cabañas (1.․, 2., 7.. y $8 . \circ$ día) la Pascua $\left(1 . \circ, 2 . \stackrel{\circ}{\circ} 8 .^{\circ}\right.$ y $9 . \circ$ día) y Pentecostés (1.ำ y $2 . \circ$ día). Para los musulmanes son el primer día del año nuevo, el décimo día de Muharram, el día 
del nacimiento del Profeta, el día de la Ascensión del Profeta, los tres días de la culminación del ayuno del Ramadán, y los tres días conmemorativos del sacrificio de Abraham. Se tratará en ambos casos de fiestas religiosas que pueden sustituir a las establecidas con igual carácter por el Estatuto de los Trabajadores, retribuidas por tanto y no recuperables; la exención requiere acuerdo entre las partes, entendemos que por las razones antedichas, dadas las dificultades que pueden crearse en las empresas por alteraciones del calendario laboral de sus empleados.

\section{h) La enseñanza}

El tema docente, aparte de su regulación en los artículos 12 a los meros efectos de los días festivos, se regula en los artículos 10 de los tres Acuerdos.

Se garantiza en su artículo 10 a los alumnos judíos el derecho a recibir enseñanza religiosa judía en los centros docentes públicos y privados concertados, en los niveles de educación infantil, primaria y secundaria, a solicitud de los interesados o de sus padres. Los centros concertados sólo tendrán que cumplir este deber si tal educación religiosa no entra en contradicción con el carácter propio del centro; excepción lógica, dado el alto número de centros docentes privados concertadós y que son confesionalmente católicos en España, y dada al mismo tiempo la libertad en que está el alumno judio de concurrir a otros centros docentes diferentes de éstos. No es necesario explicar, en este contexto, y puesto que el hecho se impone por su propia lógica, que el deber de proporcionar tal enseñanza no alcance a los centros privados no concertados.

El Acuerdo garantiza que la enseñanza religiosa judía será impartida por profesores designados y aprobados por la correspondiente Comunidad y Federación, quienes señalarán también los libros de texto; los centros docentes habrán de dar las necesarias facilidades para el desarrollo de tal enseñanza, en cuanto a locales y demás requisitos. Y se podrán organizar por las Comunidades israelitas, de acuerdo con las autoridades académicas, cursos de enseñanza religiosa judía en los centros universitarios públicos; al mismo tiempo, pueden los judios crear sus propios centros docentes infantiles, primarios, secundarios y universitarios, así como Seminarios de carácter religioso, con sumisión a la legislación vigente en la materia, a la que por otro lado se han de someter igualmente las entidades católicas que deseen hacer uso de ese mismo derecho. 
Idéntico es el contenido del artículo 10 del Acuerdo con los musulmanes y del mismo artículo del Acuerdo con las comunidades evangélicas.

\section{i) El matrimonio}

Otro de los temas jurídicos capitales en este tipo de Acuerdos es el matrimonio ${ }^{145}$, institución que durante siglos fue considerada esencialmente religiosa pero que hoy el Estado reclama como propia. En tal terreno, existe una doble problemática: la aparición del matrimonio civil, que el Estado regula y reconoce como propio fuera de toda conformación religiosa, y el reconocimiento o no de la validez en la esfera civil de los matrimonios celebrados en el seno y según las normas y ritos de las diversas confesiones religiosas.

El matrimonio civil, como realidad jurídica de exclusiva regulación estatal, en nada afecta a los Acuerdos con las confesiones religiosas. Pretenden éstas, por su parte, que el Estado no se limite a establecer un sistema de matrimonio civil obligatorio, desconociendo la tradición que considera al matrimonio como una realidad sagrada que los ordenamientos internos de las religiones conforman según sus propias convicciones al respecto. En España, el matrimonio canónico con validez civil goza de una secular tradición, y en el presente aparece regulado en el Acuerdo Jurídico de 3 de enero de 1978 entre la Santa Sede y el Estado. Resultaba, pues, una exigencia del principio de igualdad fijar en los tres Acuerdos posteriores un régimen similar para evangélicos, musulmanes e israelíes, conforme a sus necesidades respectivas. De hecho, los artículos 7 de los tres Acuerdos, que se ocupan del tema, dedican prácticamente toda su atención al tema de la inscripción registral de los matrimonios religiosos, como procedimiento para que tenga lugar su reconocimiento en la esfera civil. El Acuerdo Jurídico con la Santa Sede había marcado en 1979 la pauta en este punto, ya que en el mismo el Estado se limita a reconocer «efectos civiles al matrimonio celebrado según las normas del Derecho Canónico" estableciéndose igual-

145 Entre la todavía escasísima bibliografía sobre los Acuerdos con las confesiones no católicas, el tema del matrimonio ha sido objeto de atención especial por parte de M. D. GaRCíA-Hervás, en "Contribución al estudio del matrimonio religioso en España, según los Acuerdos con la Federación de Iglesias Evangélicas y con la Federación de Comunidades Israelitas», en Anuario de Derecho Eclesiástico del Estado, VII, 1991, págs. 589-604. 
mente la inscripción en el Registro Civil en orden al pleno reconocimiento de tales efectos ${ }^{146}$. El resto del artículo VI de aquel Acuerdo se destina a regular la validez civil de las sentencias eclesiásticas de nulidad o disolución ${ }^{147}$ y a recordar a los fieles el deber que tienen de atenerse a la doctrina de la Iglesia sobre el matrimonio.

Acerca de la propia celebración canónica, sus requisitos y modalidades, nada específicamente dice el Acuerdo, ya que la fórmula "celebrado según las normas del Derecho Canónico" supone: a) que para el Estado es matrimonio canónico el que la Iglesia dice que lo es; b) que el Estado se abstiene de intervenir de ninguna forma en los requisitos de celebración del mismo.

Igual tratamiento van a recibir en este campo las otras tres confesiones religiosas en sus respectivos Acuerdos. En los tres, el artículo 7 se abstiene de entrar en qué sea el matrimonio israelita, musulmán o evangélico; lo es el "celebrado según la propia normativa formal israelita ante los ministros de culto de las Comunidades pertenecientes a la Federación de Comunidades Israelitas de Españan, alusión exclusiva a la forma que supone que la propia confesión israelita no admitirá a la celebración formal sino a aquellos matrimonios que se atengan a sus propias normas internas relativas a los requisitos que han de reunir los contrayentes; lo es asimismo el "celebrado según la forma religiosa establecida en la ley islámica", lo que supone igual presunción; la fórmula elegida para las confesiones evangélicas es la del reconocimiento de los efectos civiles del "matrimonio celebrado ante los ministros de culto de las Iglesias...". Tres variantes, pues: el Acuerdo con los católicos se refiere a las normas del Derecho Canónico; el evangélico a la celebración ante los ministros del culto; los otros dos a la forma.

Las normas de Derecho Canónico, que afectan históricamente y aún siguen afectando a una inmensa mayoría de españoles, poseen carta de naturaleza en nuestra tradición jurídica y han influido decisivamente en la propia configuración del matrimonio civil tal como está estable-

${ }^{146}$ Sobre la regulación del matrimonio en el Acuerdo Jurídico con la Santa Sede de 3 de enero de 1979, puede verse M. López ALARCón, "Sistema matrimonial concordado. Celebración y efectos", en VV.AA., Los Acuerdos entre la Iglesia y España, cit., págs. 291-331.

${ }_{147}$ Vid. al respecto A. Bernároez CANTÓN, «La "declaración de ajuste" en el sistema matrimonial español», en Estudios de Derecho Canónico y Derecho Eclesiástico en homenaie al Profesor Maldonado, Madrid, 1983, págs. 23-56; V. REINA, "EI sistema matrimonial español", en VV.AA., Los acuerdos concordatarios españoles y la revisión del concordato italiano, Barcelona, 1980, págs. 370 y ss. 
cido y reconocido en España ${ }^{148}$; para los evangélicos, la mera mención de los ministros de culto supone dejar a éstos la responsabilidad de la correcta celebración de las nupcias, dentro de un régimen normativo también de origen cristiano, que si ha modificado incluso elementos esenciales del matrimonio tal como lo concibe la Iglesia católica, mantiene las raices cristianas acerca del significado y sentido de la unión conyugal. La remisión a la forma en los supuestos islámico e israelita la hemos comentado líneas arriba como una forma de recibir a través de los requisitos formales un ordenamiento extraño a la tradición jurídica introducida aquí desde siglos e inspiradora de nuestro Código civil y de nuestros usos sociales. Sin embargo, el Estado, en los tres Acuerdos que venimos analizando, no es tan indiferente a la forma de celebración, que no introduzca, junto a los requisitos propios de las correspondientes religiones, también sus propias exigencias a efectos de la posibilidad de la celebración del matrimonio religioso, de la forma de la misma y en consecuencia de la inscripción registral $y$, por tanto, del reconocimiento de efectos civiles. Exigencias que incluso tocan a la capacidad de los contrayentes, a los que se somete a la necesidad de una previa declaración civil de tal capacidad, novedad que no encontramos en el Acuerdo con la Santa Sede.

La exigencia está expresada de forma muy clara en el Acuerdo con los musulmanes. Su artículo 7.1 establece que "se atribuye efectos civiles al matrimonio celebrado según la forma religiosa establecida en la Ley islámica, desde el momento de su celebración, si los contrayentes reúnen los requisitos de capacidad exigidos por el Código civil». A tal propósito, deberán obtener una certificación del Registro civil que acredite tal capacidad y sin la cual su matrimonio religioso no podrá ser inscrito en dicho Registro, y por tanto carecerá de reconocimiento civil. Más aún, esa certificación solamente tiene seis meses de validez. Es obvio que se está tratando de evitar que tengan validez civil matrimonios contraídos fuera de la concepción que del matrimonio posee el ordenamiento español; en el caso musulmán, es muy claro que entre otros posibles requisitos de capacidad civil impuestos a los fieles de tal confesión, la norma piensa en la poligamia; un solo matrimonio podrá ser inscrito en el Registro y obtener reconocimiento civil, al existir en el ordenamiento español el impedimento de vínculo y carecer en consecuencia de capacidad matrimonial quien está casado, mientras perdure su matrimonio.

148 La doctrina civilista es conforme en señalar la inspiración canonística del matrimonio civil; expresamente lo señala así, p. ej., M. PeÑa Bernaldo de Quirós, Derecho de Familia, Madrid, 1989, pág. 39. 
No existe la poligamia en las confesiones israelita y evangélica, pero si que pueden darse casos de incapacidad civil que no lo sean en los respectivos ordenamientos internos de estas confesiones ${ }^{149}$. Los Acuerdos van también a exigir para los miembros de estas confesiones la capacidad civil, mediante la necesidad de un expediente previo a las nupcias que los contrayentes habrán de gestionar ante el Registro civil y que será requisito preciso para que la celebración religiosa pueda luego ser reconocida por el Estado.

La fórmula empleada en el Acuerdo con los musulmanes requiere de modo directo la posesión de la capacidad civil en los contrayentes; los otros Acuerdos llegan al mismo resultado mediante una formulación indirecta del mismo requisito. Según el Acuerdo israelita, artículo 7.2, "las personas que deseen inscribir el matrimonio en la forma prescrita en el número anterior, deberán acreditar previamente su capacidad matrimonial, mediante certificación expedida por el Registro Civil correspondiente. No podrá practicarse la inscripción si se hubiera celebrado el matrimonio transcurridos más de seis meses desde la expedición de dicha certificación". Obviamente, lo requerido es también aquí la capacidad civil; la vía concordada se ha utilizado con lógica para impedir que puedan ver reconocido su matrimonio por el Estado español quienes no puedan contraerlo según las normas de ese mismo Estado. Similar es la regulación del tema en el Acuerdo con las confesiones evangélicas.

$Y$ aún toma el Estado, concordadamente, una segunda precaución; requiere, al margen de cuáles sean los requisitos formales propios de cada confesión, que las nupcias se celebren ante el ministro correspondiente y dos testigos mayores de edad, exigencia que aparece en los tres Acuerdos, y que supone que el Estado introduce un especial requisito formal independientemente de cuál sea la norma interna de cada confesión.

La exigencia de los dos testigos junto al ministro celebrante procede del Derecho canónico, de la reforma de la forma efectuada en el Concilio de Trento, y de ahí pasó a la tradición occidental y a nuestro Derecho civil ${ }^{150}$. En consecuencia, el ordenamiento español aceptará las nupcias celebradas religiosamente a tenor de las normas internas de las confesiones, pero mantendrá siempre una adecuación del matrimo-

149 Pueden verse los requisitos de capacidad que afectan a la celebración del matrimonio en España, a tenor de la legislación al efecto, en M. Albaladejo, Curso de Derecho Civil, IV, «Derecho de Familia", Barcelona, 1982, págs. 44 y ss.

150 Vid. al respecto S. AcuÑa, "La forma del matrimonio hasta el Decreto "Ne temere" ", en lus Canonicum, XIII, 1973, págs. 137-192. 
nio, que pretenda ser civilmente reconocido, a dos exigencias claves: la capacidad civil de los contrayentes y la sumisión a una exigencia formal.

No entra en cambio el Estado en el tema del consentimiento, pues si bien nuestro Derecho civil establece vicios consensuales que pueden producir la nulidad ${ }^{151}$, el matrimonio, que en el Derecho Canónico es esencialmente un negocio consensual, para el Derecho civil es un negocio formal, y fuera de los requisitos externos de capacidad y forma deja al Derecho interno de las confesiones los problemas consensuales.

Ningún precepto, en cambio, contienen los tres Acuerdos acerca de la nulidad; el Acuerdo jurídico con la Iglesia católica sí que ha previsto la eficacia civil de las sentencias eclesiásticas de nulidad o disolución, y este tema ha merecido por su complejidad una frecuente atención por parte de la doctrina ${ }^{152}$. En consecuencia, sólo las sentencias de los Tribunales de la Iglesia católica pueden llegar a acarrear la nulidad civil del matrimonio por efecto de una decisión no adoptada por un tribunal estatal, posibilidad que los Acuerdos no toman en consideración para las demás confesiones religiosas.

\section{i) La financiación de las confesiones religiosas}

De no menor trascendencia es el tratamiento dado por los tres Acuerdos al tema de las financiación de las confesiones ${ }^{153}$, del mismo modo que ya se había concedido singular importancia a esta cuestión en

151 Vid. en M. Albaladejo, op. cit., págs. 51-52 y, con mayor detalle, en M. Peña Bernaldo de Quirós, op. cit., págs. 55-64.

152 Vid. las indicaciones de A. Bernárdez CANTón en "La "declaración de ajuste" en el contexto del sistema matrimonial español", cit. passim, y R. NAVARRo-VALLS, "El matrimonio", en J. M. GonzÁlez del VAlLE Y otros, Derecho Eclesiástico del Estado español, cit., págs. 453-457.

153 En relación con la transcendencia del tema de la financiación de las confesiones, pueden recordarse estas palabras de J. M. González deL VALLE, Derecho Eclesiástico español, cit., pág. 163: «El tema de la asistencia religiosa común, acaba resolviéndose en el tema del régimen económico de las confesiones religiosas. El Estado debe crear unas condiciones tales que hagan posible esa asistencia religiosa, huyendo de extremos que históricamente se han dado: permitir que las confesiones religiosas acumulen ilimitadamente riqueza o permitir que no sea posible una infraestructura de asistencia religiosa en razón de condicionamientos económicos". 
los Acuerdos con la Iglesia Católica de 1979, ya que uno de ellos se dedicó por entero a materias económicas ${ }^{154}$. Lo que no es de extrañar, dada la prevalencia de la cuestión económica sobre tantas otras en la sociedad moderna, en la que la infraestructura de la economía condiciona y aún permite - hasta de modo radical - la existencia y funcionamiento de las instituciones. La larga experiencia de las relaciones con la Iglesia católica en este campo había de resultar decisiva para el Estado ${ }^{155}$, a la hora de establecer sus relaciones económicas con las diferentes Confesiones.

Un largo artículo 11, similar en los tres textos, regula la materia, de un modo que SOUTO ha resumido como sigue: «A) Financiación propia. Se reconoce a las confesiones signatarias de los Acuerdos el derecho a recabar libremente de sus fieles prestaciones, organizar colectas públicas y recibir ofrendas y liberalidades de uso. B) Régimen fiscal especial. Operaciones no sujetas a tributo: las prestaciones, colectas y ofrendas, la entrega de publicaciones de carácter religioso y la actividad de enseñanza religiosa. a) Exenciones fiscales.-Del Impuesto sobre Bienes Inmuebles y de las Contribuciones especiales: Estarán exentos los lugares de culto, los locales destinados a oficinas de la confesión respectiva y los centros de formación de los ministros de culto.-Del Impuesto sobre Sociedades: Además de lo previsto en el artículo 5. (apartados 2 y 3) de la Ley $61 / 1978$, de 27 de diciembre, estarán exentos los incrementos de patrimonio a título gratuito destinados a actividades religiosas y asistenciales.-Del Impuesto sobre Transmisiones Patrimoniales y Actos Jurídicos Documentados: Quedarán exentos los bienes, derechos adquiridos y que se destinen a actividades religiosas y asistenciales. b) Beneficios fiscales. Las confesiones (Federaciones y Comunidades), así como las asociaciones $y$ entidades creadas por ellas y destinadas a actividades benéfico-docentes médicas u hospitalarias con asistencia social tendrán derecho a

154 Vid. sobre el Acuerdo económico de 1979 A. PANIzo y Romo de ARCE, "Soluciones conceptuales al actual sistema económico de la Iglesia católica en España", en Revista de la Facultad de Derecho de la Universidad Complutense, 79, 1991-92, págs. 219-229; A. ARZA, "Principios V sentido del Acuerdo sobre asuntos económicos" y "El sistema de aportación estatal", en VV.AA., Los Acuerdos entre la Iglesia y España, cit., págs. 589-606 y 607-623; F. DE LUIS, "Régimen tributario de la Iglesia y de los entes eclesiásticos", en la misma obra, págs. 625641.

155 Puede ser de interés conocer los puntos de vista de los economistas sobre la normativa al respecto de la Iglesia Católica en sus relaciones con el Estado. Vid., p. ej., C. Albiñana García-QuintanA, «El régimen jurídico-económico de la Iglesia en España", en VV.AA., Constitución y relaciones Iglesia-Estado en la actualidad, Salamanca, 1978, págs. 103-123. 
los beneficios fiscales que el ordenamiento jurídico reconozca a las entidades sin fin de lucro $y$, en todo caso, a los que se concedan a las entidades benéfico-privadas. c) Deducciones. La legislación fiscal regulará el tratamiento tributario aplicable a los donativos que se realicen a las confesiones citadas con las deducciones que, en su caso, puedan establecerse" ${ }^{166}$.

De hecho, debe tenerse también en cuenta que buena parte de la actividad asistencial de las confesiones - y el modelo de la Iglesia católica es en esto paradigmático - resultará verterse hacia la beneficencia en sus diversas formas, hacia la caridad desde sus manifestaciones más elementales hasta las más complicadas. En este terreno, la actividad del Estado ha de resultar subsidiaria y no sustitutoria, y la financiación de las confesiones posee desde este punto de vista una particular importancia ${ }^{157}$.

\section{k) La protección del patrimonio}

Anejo al tema económico aparece el de la protección del Patrimonio artístico-religioso y de determinadas marcas alimenticias y cosméticas; es cuestión que no afecta a las Comunidades evangélicas, que por un lado carecen en España de un patrimonio de ese tipo y por otro no poseen preceptos internos relativos a los alimentos, como sí es en cambio el caso de judíos y musulmanes. Los artículos 13 de los Acuerdos con estas dos Federaciones muestran la voluntad de colaboración entre el Estado y las dos Confesiones para conservar y utilizar aquel patrimonio, mientras los artículos 14 toman precauciones para el registro, condiciones sanitarias y propiedad industrial de las marcas comerciales correspondientes.

156 J. A. Souto, op. cit., págs. 552-553.

157 W. LEISNER, "La actividad caritativa como característica de la Iglesia en el moderno Estado social", en VV.AA., Simposio Sudamericano-alemán sobre Iglesia y Estado (editado por J. Terán Dutari), Quito, 1980, págs. 149-160. 


\section{I) La asistencia religiosa en centros estatales}

Se hizo arriba alusión a la actividad positiva que en ocasiones se requiere del Estado en orden a la asistencia religiosa. Si puede nacer tal requerimiento del deber de los poderes públicos de tomar las medidas precisas para que sean posibles determinados actos y funciones cultuales, específicamente señalan los artículos 9 de los tres Acuerdos la obligación en que está el Estado de garantizar de modo muy concreto determinados derechos de asistencia religiosa.

Tales artículos garantizan "el ejercicio del derecho a la asistencia religiosa de los internados en Centros o Establecimientos penitenciarios, hospitalarios, asistenciales $\mathrm{u}$ otros análogos del sector público, proporcionada por los ministros de culto que designen las Iglesias respectivas, con la conformidad de la FEREDE, y debidamente autorizados por los Centros o establecimientos públicos correspondientes" (Acuerdo con la Federación evangélica). El acceso de los ministros a tales centros será, a tales fines, libre y sin limitación de horario, y la asistencia religiosa se prestará con el debido respeto al principio de libertad religiosa y con observancia de las normas de organización y régimen interno de los Centros. Podrán utilizarse al efecto locales propios de los Centros, pero la FEREDE habrá de correr con los restantes gastos que la asistencia espiritual origine.

El mismo artículo del Acuerdo islámico mantiene similar legislación, añadiendo como notas propias la obligación en que está la Dirección de los Centros de trasmitir a la Comunidad islámica la solicitud de asistencia de los internados y la mención de los ritos fúnebres islámicos cuando sean necesarios. Idéntico tratamiento recibe el tema en el Acuerdo con los israelitas.

Es de notar que esta normativa resulta de aplicación a los casos concretos del precepto general contenido en la LOLR, artículo 2.9-3, si bien la generalidad de este texto se ha visto concretada en los Acuerdos de un modo en cierta manera diferente del previsto en la LOLR.

En efecto, la LOLR preceptúa exactamente que "los poderes públicos adoptarán las medidas necesarias para facilitar la asistencia religiosa en los establecimientos públicos..."; ; parecería por tanto que la competencia y el deber, o si se quiere el deber y la consiguiente competencia, de establecer las medidas precisas para hacer efectivo el derecho de asistencia religiosa en los Centros de dependencia estatal, corresponden a la 
Administración Pública. Sin embargo, el Estado, por un lado, ha pactado esas medidas con las confesiones, renunciando al hacerlo a su exclusiva competencia al respecto previamente proclamada por él mismo; por otro lado, en el pacto se acepta que los ministros de las diversas confesiones que han de prestar la asistencia requerida deban recibir previamente la aprobación de la autoridad estatal. Se añade que se atendrán estos ministros a las normas de régimen interno de los Centros. Esta última exigencia es totalmente lógica. El requisito de la aprobación de los ministros por parte del poder público para poder cumplir sus deberes religiosos supone una renuncia de las confesiones a su total autonomía en la materia, en correspondencia tal vez a la autolimitación que se impuso el Estado de pactar una materia en la que hubiese podido dictar unilateralmente la oportuna normativa. 